\begin{tabular}{c}
\hline GEOLOGY OF JEFFERSON COUNTY \\
BY A. UDDEN. \\
J. A.
\end{tabular}




\title{
GEOLOGY OF JEFFERSON COUNTY.
}

\author{
BY J. A. UDDEN.
}

\section{CONTENTS}

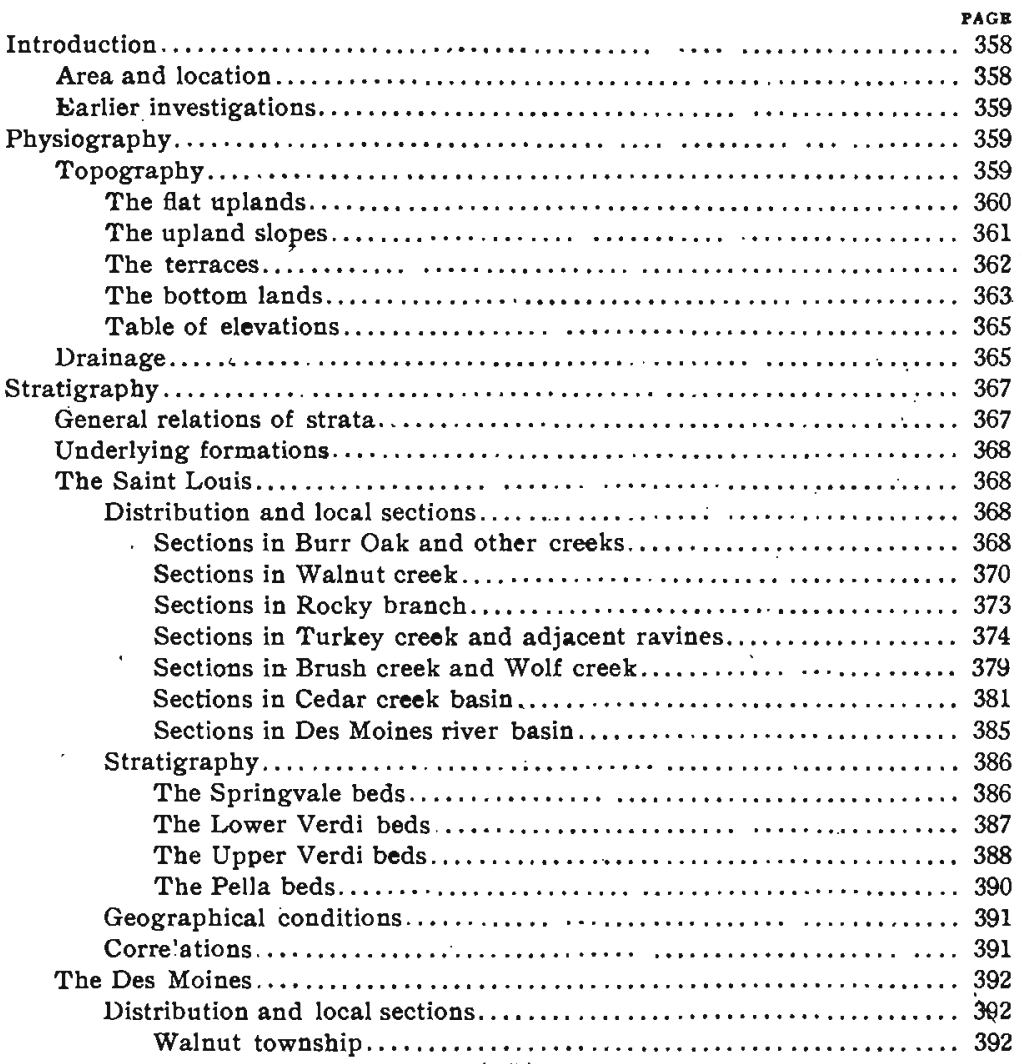

(357) 
(1)

I.cckridge township ........................... 393

Round Prairie township ......................... 395

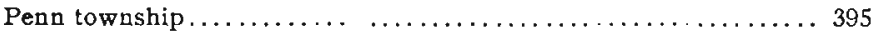

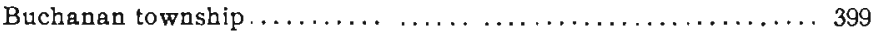

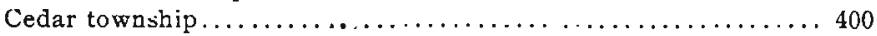

Black Hawk township $\ldots \ldots \ldots \ldots \ldots \ldots \ldots \ldots \ldots \ldots \ldots \ldots \ldots \ldots \ldots$

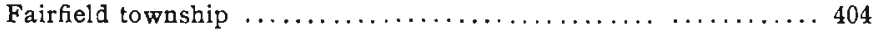

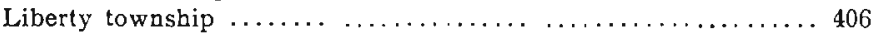

Polk township..............................4 409

Locust Grove township ........................ 409

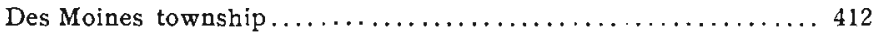

Thickness of the Des Moines ......................... 413

General character................................ 414

Correlations................................... 417

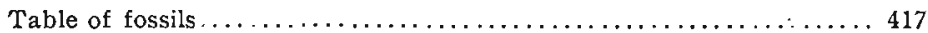

Erosion interval................................... 419

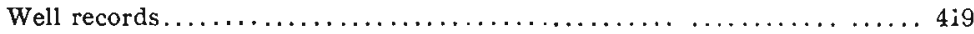

The Pleistocene.................................... 422

Associated gravels................................. 422

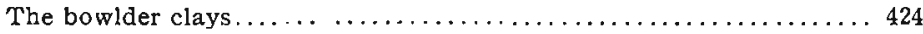

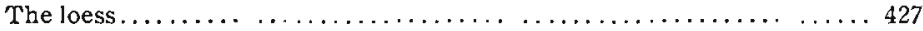

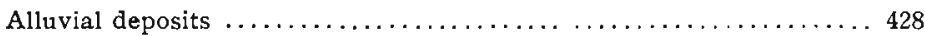

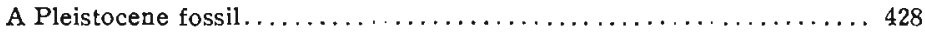

Geological structure . . . . . . . . . . . . . . . . . . . . . 429

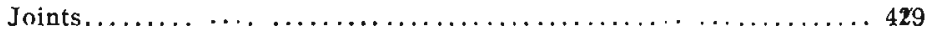

Glacial scorings................................ 430

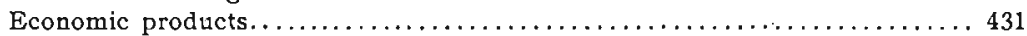

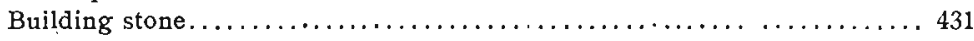

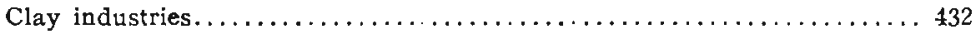

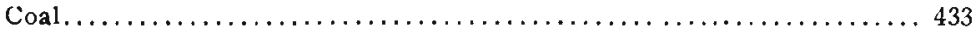

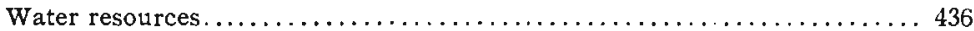

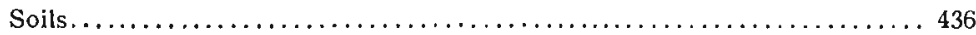

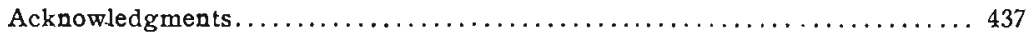

INTRODUCTION.

AREA AND LOCATION.

Jetferson county comprises an area of 432 square miles. It lies in the southeastern part of the state, . extending to within thirty-six miles of the Mississippi river and to within twenty miles of the Missouri line. It includes all of ranges eight, nine, ten and eleven west of the fifth principal meridian and all of townships seventy-one, seventy-two and seventy-three north. Or the east it is bounded by Henry county, on the south by Van 
Bureu, on the west by Wapello, and on the north by Keokuk and Washington counties, being included in a rectangle measuring twenty-four miles from east to west and eighteen miles from north to south.

\section{EARLIER INVESTIGATIONS.}

The geologists who have previously made a study of the formations exposed in this county are $\mathrm{A}$. $\mathrm{H}$. Worthen, who made a rapid survey of the region in the summer of $1857^{*}$, and Prof. C. A. White, who was State Geologist ten years later. $\dagger$ Not being traversed by any of the larger streams, to which the attention of these early surveys was necessarily mainly directed, the field was not as closely studied here as in some other counties, and the published reports were very brief, giving only the main features. More data, bearing especially on the production of coal, were lately obtained and published by C. R. Keyes in the volumes of the present survey. $\neq$ Recently Mr. Frank Leverett has described and explained the significance of a high terrace which occurs along the Skunk river in the northeast part of the county. $\S$

\section{PHYSIOGRAPHY.}

$$
\text { TOPOGRAPHY. }
$$

The ruling feature in the topography of the county is the surface of an old drift plain, which has an average elevation for the whole area of about 770 feet above sea level. It has a general slope to the south of about two feet per mile, and to the east of nearly three feet per mile, while from the northwest to the southeast its general descent is about five feet to the mile. This drift plain is the result of the deposition of the bowlder clay by extensive inland ice fields. It is far from being in its original condition. The long continued action of erosion subsequent to the disappearance of the ice has greatly changed its original aspect. River's, creeks and smaller tributary streams have sunk their valleys and gullies into it until their beds now lie from 50 to 150

- Worthen; Geology of Iowa; James Hall, Vol, I, pp. 231-239, 1858

+ Whjte; Second Anqual Report State Geologist, pp. 94-96, 1868; also Geslogy of Iowa, Vol. II, p 273, ]870.

$\ddagger$ Keyes; Iowa Geol. Surv.. Vol. I. 2. 120; also Vol. II, pp. 393-402.

\$ Leverett; Monograph XXXVIII, U. S. Geol. Surv., p. 92. 
feet below its surface. Much of its surface, especially such parts as hare not suffered erosion, has later been buried by a covering of loess, varying in depth from eight to sixteen feet. In this modileed condition the land now presents various topographic features, which may be classified as: (1) flat uplands ; (2) upland slopes; (3) terraces; and, (4) bottom lands.

The Flat Uplands. - The flat uplands are such parts of the original drift plain as have not yet been perceptibly affected by erosion through the backing up of the drainage lines and drainage slopes. They lie between these, forming the divides, and their borders run into the slopes. Except in a few places near some of the headwaters of the longest tributaries to the larger streams, this border is quite well marked by a gradual but well marked change in slope from usually less than fifty feet in a mile on the upland plain to several or many times this amount in the slopes leading down into the smallest drainage branches. Midway between two adjacent drainage basins the upland flats are nearly or quite level except for the general tilting of the whole plain, but as we approach the drainage lines on either side there is usually a slight, almost imperceptible slope. In the direction of the larger streams this slope seldom amounts to more than ten feet per mile, but on the sides of those strips of upland which extend from the main divides to form the divides separating the smaller ravines, it is frequently more.

The surface of these uplands is otherwise notably flat and even. It is highest above the headwaters of the longest streams, and its lowest stretches often appear in places where streams join. But all of these differences in elevation are invariably very gentle and gradual. Only a single instance of a moundlike elevation on the uplands was noted in the course of the survey. This is a little north of the center of section 7 in Liberty township, about three-quarters of a mile northwest of Libertyville. At this place the surfape has a rather well marked bulge of ten or fifteen feet above the general level. This elevated tract covers an area of some forty acres. Shallow depressions are somewhat more common along the highest lines of the widest divides and these may have an area of from a fraction of an acre to several acres. 
Estimates made on the several townships give an average of from one-fourth to one-fifth of the total area of the county to the fiat uplands. They are most extensive in Polk, Black Hawk and Des Moines townships and have been most extensively invaded by the creeks in Walnut, Lockridge and Locust Grove. In Polk township there are entire tracts which are a mile wide, but otherwise the habit of the flats is to form strips from twenty rods to half a mile in width between the streams. Four-fifths of their whole extent in this county is believed to consist of such strips. In not a few instances these reach far out from the main divides and terminate in the very bluffs of the main streams. In Jefferson county this is perhaps most common on the south side of Cedar river.

The Upland Slopes.-The upland slopes extend from the sinuous nargins of the flats down to the bottoms of the streams. They occupy the greater part of the surface of the county. The greatest pitch of these slopes prevails in places where the larger streams have encroached upon the uplands by widening the bottom lands. Recent instances of sapping are however quite scarce, especially in places where the streams do not cut bolow the base of the drift. The meanders of some of the larger streams may be followed for several miles without coming to a place where the bluffs are now being attacked so as to expose fresh drift. The width of the slopes is most commonly from oneeightl to one-half mile and the descent is from 50 to 1.50 feet. The latter height is attained in some places in Walnut township along the tributaries to Skunk river and in the southwest part of Des Moines township approaching the- Des Moines river. The slopes of least relief occur along the headwaters of the longest tributaries to the larger streams. The greatest pitch is nearly always somewhat below the middle of the slope. Below this the slope continues downward in a curve having a concave profile, and above, it runs in a curve which has a somewhat extended convex profile. Following the slopes in the direction of their linear extension, on the sides of the water-ways, we find that they form an endless succession of loops and cusps determined by the course of the larger streams, creeks and the ultimate branches of all their affluents. It is evident that the slopes 24 G Rep 
are the result of the work of erosion performed by the present drainage. The streams have cut out and carried away the material which once filled the valleys. Their attitudes are everywhere an expression of this work, and of the conditions which have affected it. As an instance we may mention a feature, first noted and explained by Professor Calvin in other parts of the state. In creeks running from east to west the slopes on the south side descend more rapidly than the bluffs on the north side. The latter have suffered more rapid reduction owing to the more direct exposure to the sun's heat and consequent greater energy of the melted snow-water during thaws. On the slopes facing north, on the other hand, the snow melts more gradually and the slow seeping of the snow-water there has been less effective in carrying down with it the debris of the land.

The Terraces.- The work of carving out the valleys to their present depth has not proceeded at a uniform rate. At differeni places along the streams there are seen occasional remnants of old valley bottoms, or terraces, occupying higher levels than the present ones. The highest of these old valley bottoms in this county was first observed by Mr. Frank Leverett during his studies of the Illinoian drift. It consists of a few obscure shelves along the west bluffs of the Skunk river, in the northeast corner of the county. These have an elevation of about 125 feet above the level of the river. The best instance seen is probably on the east half of section 11 in Lockridge township, where an area of about a quarter section of the margin of the upland is some forty feet lower than the uplands to the west. This branch is believed to have been a part of the bottom of a large stream, which came down the Crooked creek valley at the time of the greatest westward extension of the Illinoian glacial lobe.* Along Cedar creek one terrace has an elevation of about eighty feet above the stream. Considerable tracts of this terrace luave been preserved along its lower course in this county where the rock-bound nature of the, land has prevented extensive meandering of the river. It is quite conspicuous in the south half of section 27 and in the southwest quarter of section 26 , on the north side of the creek, and also in the north halves of

* Leverett; Moncgraph XXXV.II, U. S. Geol. Surv, , p. 92. 
sections 35 and 36 , on the south side of the creek in Cedar township. In the adjoining south quarters of sections 33 and 34 in Round Prairie township, another quite extensive remnant follows the creek on the north side. Other instances of benches of nearly the same height occur in the west half of Locust Grove township, as in the northeast quarter of section 28 and in places in sections 21 and 20. Remnants of old bottoms rising some twenty or thirty feet above the present flood plains are more frequent. They occur on the larger as well as on the smaller streams, as may be seen along the Skunk river bluffs in section 23 in Walnut township, under the Cedar river bluffs in section 13 in Liberty township, along Brush creek in section 25, along Turkey creek in section 11 in Lockridge township, and along Walnut creek in sections 28 in Walnut and 25 in Penn townships. It may be that these terraces were made at times when the general elevation of the land was less than it is at present and thus affected the work of erosion. But another circumstance mar perhaps as well have produced some of them, judging from appearances in this county. In Cedar creek the surface of the hrghest terrace lies only slightly above the upper surface of the bed rock, which is a solid and compact limestone, and which crosses the valley as a broad and durable sill several miles wide in the southeast part of the county. Evidently when the cutting reached this sill it was for a long time arrested, until the channel was sunk into this rock. The hard rock is many times more difficult to remove than loose drift. The creek must have established a flood plain at the level where its work was arrested by this sill and it must have spent its energy above this place in widening its valley up to the same time. The writer believes that a correct interpretation both of the age and of the causes of the terraces in this region will require a much more extensive comparative knowledge of their features than we at present possess.

The Bottom Lands. - The bottom lands, or the present flood plains, are the flat lowlands which may be inundated during high floods. Their surface lies at an elevation of from fifteen to thirty feet above the bed of the streams, and in this county from 150 feet below the upland flats nearest the larger streams 
to less than seventy-five feet below the same uplands in case of the narrow alluvial tracts following the smaller divisions of their tributaries. The bottom lands of Skunk river average a little more than a mile in width, being broadest just above the mouth of Walnut creek where they reach a mile and a half from bluff to bluff. They have an elevation of about 585 feet above sea level, sloping south about two feet per mile. The flood plain of Cedar creek varies greatly in width. In Round Prairie and in the east half of Cedar township it is narrow and at times entirely absent. The stream winds along in a rocky canyon with walls from forty to seventy feet high and from a few rods to perhaps one-fourth of a mile apart. Above the mouth of Crow creek it widens out and for the next five miles maintains a width of from half a mile to a mile. Then for about three miles within the boundaries of Fairfield township it narrows to half a mile. Above this it again widens to about three-fourths of a mile and more, in the east half of Locust Grove township. For the remaining four miles of its course in this county it is mostly less than a quarter of a mile wide. Examining the material on which the work of erosion has been performed by this stream we find that the width of its bottoms corresponds inversely to the hardness of the materials on which it has had to work. In the region of the limestone the bottorns are narrow or none. In the region where the Coal Measure shales and limestones have been worked upon the width is from one-fourth to one-half mile, and where there is only drift the bottoms widen out to as much as a mile. The elevation of the Cedar creek flood plain is about 685 feet above sea level at the west boundary of the county and about 620 feet below the mouth of Rock creek on the south boundary. The bottoms of the smaller streams, such as Walnut creek and its branches, Turkey, Brush, Wolf, Rock and Crow creeks, the two Competine creeks, Black creek and Lick creek average at least an eighth of a mile in width and sometimes expand to twice this measure, vanishing only within a mile or so of the ultimate sources of the streams. The habit of contracting in places where the channel goes below the surface of the bed rock is in their case even more conspicuous. It is universal and the writer has not observed a single exception to the rule that the bottoms are narrow in places 
where outcrops of bed rock occur, and wide where the bluffs are composed of drift all the way down. The extent of the contraction of the valleys is usually proportionate to the rise of the rock. The ligher this lies the more narrow the valley, and where the valleys dilate farthest it is useless to look for good exposures of the country rock.

\section{DRAINAGE.}

The drainage bears everywhere the mark of maturity and has suffered no recent changes. The larger streams probably follow drainage lines existing before the drift was laid down. The courses of the minor stream have evidently been established subsequent to the time of the ice invasions. About fifty square miles of the area of the county drain into the Des Moines system. The remaining 382 square miles belong to the Skunk river system and is divided among its several tributaries as follows:

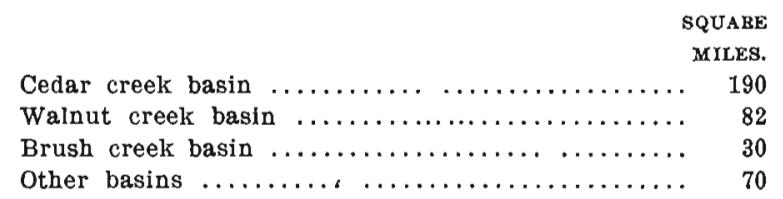

The Cedar creek basin averages some twelve miles in widtl and extends through the south part of the county from westnorthwest to east-southeast, reaching nearly to the northwest corner. Its north tributaries reach out from five to eight miles, while those on the south side drain a strip only about three or four miles wide. Most of the smaller drainage basins are likewise elongated in form and their longer axes have the same general trend. The exceptions to this rule consist of some basins which drain more nearly either north or south. These are less elongated in outline and as a consequence the branches of their creeks spread more. Such are the tributaries to the Des Moines river in the southwest part of the county and all the smaller tributaries to Cedar creek.

The land is at present almost everywhere well drained. The only exceptions consist of some few tracts of low bottom land and some shallow depressions on the widest upland flats, already referred to. Before the land was brought under cultivation these 
shallow depressions on the uplands were partly filled with water after rains and this sometimes stood for an entire season. These pools were sought by the hunters, in the pioneer days, for geese and ducks. Some were conspicuous enough to receive local names. "Devil's Lake" covered at times a few acres a little east of the center of the southwest quarter of section 20 in Polk township. Other ponds occurred in the southwest quarter of section 12 and in section 13 in the same township, in the northeast quarter of section 32 in Black Hawk township, and in the southwest quarter of section 12 and the northeast quarter of section 2 in Fairfield township. At that time the uplands were less well drained than at present, and where we now find the best farms the land was at first regarded as being too wet for agricultural purposes. Most or all of the rainfall was then, as it is now, absorbed by the ground or evaporated, the surface slope being too small to drain it off, before it has time to be taken up by the porous loess soil. It escapes from there only by slow seepage and by evaporation.

T.ABLE OF ELEVATIONS.

\begin{tabular}{|c|c|}
\hline STATION. & ALTITODE. \\
\hline 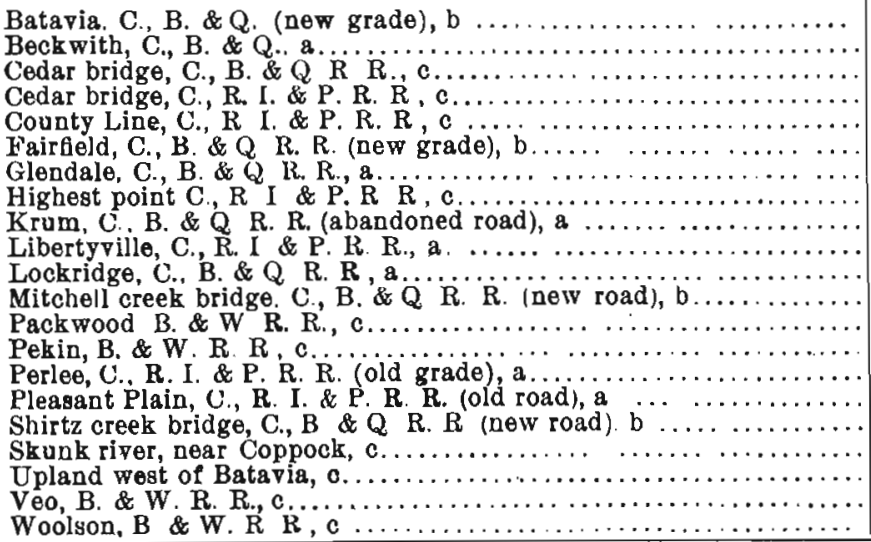 & $\begin{array}{l}725 \\
777 \\
702 \\
675 \\
788 \\
775 \\
758 \\
805 \\
692 \\
768 \\
732 \\
715 \\
82 C \\
835 \\
679 \\
749 \\
720 \\
570 \\
790 \\
790 \\
784\end{array}$ \\
\hline
\end{tabular}

Authority: (a) Gannett's Dictionary of Altitudes in U. S.; (b) Engineer's office, C., B. \& Q. R. R.; (c) Aneroid measurements by the author. 


\section{STRATIGRAPHY.}

\section{General Relations of Strata.}

In the west half of the north tier of townships the streams have not cut through the drift and no rock exposures have been observed. The thickness of the drift appears to be quite uniform, some 125 feet, although one well record gives 180 feet. Immediately under this lie the Coal Measures, averaging perhaps nffty feet in depth. These have been quite extensively removed on the lowlands, however, and in the northeast part of the county they are absent even on the uplands. The Coal Measures in turn rest on the Saint Louis limestones, shales and sandstones, which belong to the Lower Carboniferous and which average about one hundred feet in depth. The following table will further elucidate the general arrangement of these divisions:

\begin{tabular}{|c|c|c|c|c|}
\hline GROOP. & SYSTEM. & SERIES. & STAGE. & SUB-STAGE. \\
\hline \multirow{5}{*}{ Cenozoic. } & \multirow{5}{*}{ Pleistocene. } & Recent. & Alluvial and terrace. & \\
\hline & & Post-Kansan. & Loess. & \\
\hline & & \multirow{3}{*}{ Glacial. } & Kansan & \\
\hline & & & Aftonian. & \\
\hline & & & Albertan. & \\
\hline \multirow{4}{*}{ Palæozoic. } & \multirow{4}{*}{ Carboniferous. } & $\begin{array}{l}\text { Upper Carbon- } \\
\text { iferous. }\end{array}$ & Des Moines. & \\
\hline & & \multirow{3}{*}{$\begin{array}{l}\text { Lower Carbon- } \\
\text { iferous. }\end{array}$} & \multirow{3}{*}{ Saint Louis. } & Pella. \\
\hline & & & & Verdi. \\
\hline & & & & Springvale. \\
\hline
\end{tabular}


Underlying Formations.-Under the rock seen in the lower. most exposures there is some thirty feet of limestone, with some shale and sandstone, as is shown in the deep well at Ottumwa and also known from exposures in the counties of the east. This is mainly the Augusta limestone, also known as the Keokuk and the Burlington. Below this the Kinderhook shales continue for some 150 feet, under which there is nearly 500 feet of limestone with some included shale. Then the Saint Peter sandstone follows, about 100 feet in thickness, and limestone with some shale run on for 900 feet below this, which is the greatest depth reached by explorations in this region.*

\section{Carboniferous System.}

THE SAINT LOUIS.

The lowest formation which appears in exposure in Jefferson county is the Saint Louis, belonging to the upper part of the Lower Carboniferous system. It consists of limestone, marls, sandstones and dolomites of quite varied characters and has an exposed thickness of some eighty feet within the boundaries of the county.

The outcrops of the Saint Louis are to be found only in the valleys of the streams, where the overlying Coal Measures, which constitute the bed rock over most of the area, have been removed. In the northeast half of Walnut township and in places farther west along the north boundary of the county the drift no doubt rests directly on the Saint Louis even in the uplands, but the areas of these upland occurenves can be made out only approximately owing to the thickness of the drift.

Sections on Burr Oak and other Creeks.-In a ravine which runs cast along the south line of section 1 in Walnut township, and in the bluffs to the north, this terrain appears as high up as from 50 to 150 feet above the level of the Skunk river. It occurs also in the northeast quarter of section 2 , in the northwest quarter and near the southwest corner of section 11. On Burr Oak creek it is seen at intervals from the east line of section 8 and all the way down to the junction of this creek with the

\footnotetext{
* Norton; Iowa Geol Surv., Vol. VI, p. 319.
} 
Walnut. In sections 8 and 16 there is limestone, in section 22 the rock consists of arenaceous limestone or sandstone, and still further down, in section 26, there are ledges and seams of dolomitic limestone, marls, and blue shale. These latter beds represent the lowermost division of the Saint Louis beds exposed in the county. A detailed description of two exposures is as follows:

I SECTION IN THE WEST B INK OF BURR OAK CREEK, A LITTLE NORTH OF THE CENTER OF THE SW, y/ OF THE SW. y/A OF SEC. 26, WALNUT TOWNSHIP.

\section{FEET.}

9. (2) Bluish white, laminated, limestone of very fine texture .................... 1

8. (2) Yellow, marly, dolomitic material ...... 5

7. (2) Yellow, wavy-bedded mortar-rock with a pure calcareous, and slightly porous matrix, making more than half of the bulk of the rock and being in places without sand. The imbedded rounded sand grains averaging somewhat less than one millimeter in diameter in all samples examined, but range up to five times this size. The largest of the siliceous fragments are angular and

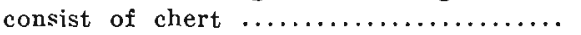

6. (2) Yellow, mortar-rock, with a pure calcareous and slightly porous matrix. The sand constitutes about one-half of the bulk of the rock, and consists of rounded grajns of quartz averaging less than one millimeter in diameter, and ranging up to two millimet.rs. There are also fragments of chert from one-half to three centimeters in diameter. These have their surfaces frequently marked by shallow concave bcllows, apparently produced by etching, as by solution. Yet the textnre of the bed is very variable. In places it is traversed by thin, long and curving fissures which are filled with clear calcite $\ldots \ldots \ldots \ldots \ldots \ldots \ldots \ldots \ldots \ldots$

5. A band of yellowish gray chert of rather even

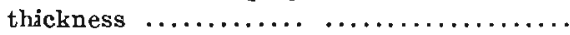

4. (1) Yellow or blue, marly, magnesian limestone with band of chert. A hand specimen was observed to be without any sand. It bad minute porosities, apparently due to the removal of some organic fragments. Some of these were minute, straight, tubules. Imprints of a Productus were noted ..... 31/2 
3. (1) Yellow and somewhat indurated magnesian

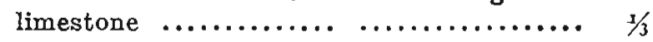

2. (1) Greenish gray, shaly marl with irregular loafshaped concretions of tough, gray quartz.. 3

1. (1) Fine-graired, almost compact and partly dolomitic limestone of yellow color and with streaks of imbedded fine sand. On fresh fractures there were seen minute, dark, dendritic blotches as of manganese oxide. The ledge is traversed by thin curving fissures, which are bealed mostly with a dark ferruginous cement. Seen in bed of the creek to a depth of about........... 1

II. SECTION IN THE WEST BANK OF BURR OAK CREEK, NEAR THE CENTER OF THE SW. $/ / 3$ OF THE SW. $/ / 6$ OF SEC. 26, WALNUT TOWNSHIP.

5. (1) Dull yellow, maguesian limestone ........

4. (1) Yellow dolomitic marl $\ldots \ldots \ldots \ldots \ldots \ldots \ldots \ldots . \ldots$

3. (1) Yellow, apparently lenched and somewhat dolomitic limestone of fine terture containing fragments of a Productus and Fen-

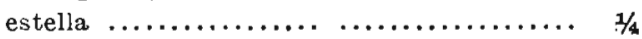

2. (1) Dull yellow marl, somewhat dolomitic ..... 3

1. (1) Greenish, slightly calcareous hale containing irregular shaped, loaf-like concretions of a tough gray quartz, somewhat resembling geodes, but differing from these in always having a solid center and in showing no crystals $\ldots \ldots \ldots \ldots \ldots \ldots \ldots \ldots \ldots \ldots . . \ldots \ldots$

Sections on Walnut Creek.-Following Walnut creek we find the same succession. The lowest rock exposed in the bed of this creek, about one-fourth of a mile west of the center of section 2 , Lockridge township, is identical with number 4 in section 1 above, except that it is slightly less dolomitic and that it contains occasional small kernels, or lumps, of compact calcareous material, as if the process of dolomitization were less far advanced. Along the bend to the south which this stream makes in sections 2 and 3 these dolomitic beds are exposed, and above them we find sandy, cross-bedded limestones rising thirty or forty feet. These continue for four miles above and are in turn overlain by brecciated, more calcareous and less sandy limestone ledges, as may be seen in sections 19, 20 and 29 in Walnut township, and in sec- 
tions 24, 25 and 26 in Penn township. Still farther up, as in sections $21,23,26$ and 27, yet higher beds occur above these, in the banks of the main creek and its forks and these consist of quite evenly bedded gray limestones and marls. The crossbedded sandy rock is particularly well exposed in the right bank of the creek along the east line of the northeast quarter of section 29 in Walnut township. The relation and characteristics of the different divisions are well represented in the following sections:

11. SECTION IN A RAVINE AŃD IN A STONE QUARRY IN THE SW. 3/4 OF THE SE . 3 OF SEC. 3, LOCKRIDGE TOWNSHIP.

5. (3) White, weathered limestone-breccia, weathering into angular fragments. Some of this breccia is arenaceous, with imbedded pieces of pure white limestone. Occasionally an almost pure sand fills the interstices between the blocks and fragments of the bruccia. (Seen above the stone quarry.) ....................... 5

4. (3) Yellow clay and $\operatorname{marl} \ldots \ldots \ldots \ldots \ldots \ldots \ldots .31 / 2$

3. (2) Porous limestone of dark gray color. It contains occasional nodules of chalcedonic quartz. In some places it gives a faint bituminous odor, when struck by the hammer. It contains a small and variable amount of well rounded sand grains and also of calcareous fragments of a different and finer texture from that of the main matrix. In places the rock contains scattered clear crystals of calcite measuring about one-eighth of an inch in length. These are occasionally dissolved out leaving small cavities. Some of the larger quartz sand grains and small pebbles, which this rock contains, have shallow, concave depressions on the surface. These have apparently been produced by solvent action of the grouud water. In three rock specimens, carefuliy examined, different stages of this etching were noticed. Its extreme result is the production of a porous, calcareous rock with only a few imbedded, angular, siliceous particles. (The main quarry rock in Walgren's quarry) $\ldots \ldots \ldots \ldots \ldots \ldots \ldots \ldots \ldots \ldots$.

2. (2) Pronous, grayish yellow limestone, somewhat irregularly bedded, and considerably af- 
fected by weathering and leaching (exposed below the quarry) $\ldots \ldots \ldots \ldots \ldots \ldots, 5$

1. (1) Dolomitic marl, almost stony above and more shaly below. When crushed and examined under the microscope the marly material is seen to consist of very small rhombohedral crystals, which effervesce tardily in moderately strong acids. (Exposed in a ravine below the quarry.) $\ldots \ldots \ldots \ldots \ldots, 8$

IV. SECTION IN THE LEFT BANK OF WALNUI CREEK, ABOUT TWENTY RODS SOUTHEAST OF THE CENTER OF THE SW. $1 / 4$ OF SEC. 20 , WALNUT TOWNSHIP.

FEET.

2. (3 \& 4) Gray, partly brecciated limestone (not

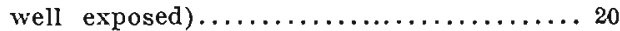

1. (2) Sandstone and arenaceous limestone, trequently cross-bedded $\ldots \ldots \ldots \ldots \ldots \ldots \ldots 25$

V. SECTION IN THE SOUTH BANK OF WALNUT CREEK, ABOUT ONE FIFTH OF A MILE WEST OF THE EAST LINE OF SEC. 19, WALNUT TOWNSHIP.

3. (4) Gray, hard limestone, slightly brecciated and broken, and with some thin seams of marl between some of the ledges .......... 10

2. (3) A stony marl containing a small and almost spherical Seminula in abundance, and lumps of concretionary limestone, and of oolitic limestone. The oolitic spherules average one half of a millimeter in diameter and are mingled with occasional larger lumps of compact limestone. Most of them are ellip-tical in cross section and consist of a dark central plate which is surrounded by a lightcolored thick envelope, which again is surrounded by a thin crust of dark color on the outside $\ldots \ldots \ldots \ldots \ldots \ldots \ldots \ldots \ldots \ldots$. $1 / 3$

1. (3) Flexed, faulted and brecciated ledges of hard gray limestone $\ldots \ldots \ldots \ldots \ldots \ldots \ldots \ldots \ldots, 10$

VI. SECTION IN THE NORTH BANK OF WALNUT CREEK, AT THE SOUTHEAST CORNER OF SEC. 24, PENN TOWNSHIP.

(2) Slanting and cross-bedded ledges of limestone alternating with more massive ledges of mortar-rock. The latter is in places seen to have promiscuously arranged, curving, tubular cavities of variable diameter, which are 
filled with calcite. The mortar-rock consists of a calcareous matrix making from ten per cent to forty per cent of the bulk, and containing imbedded well-rounded sand grains, the prevailing size of which in one hand specimen was from one-third to onefourth of a millimeter in diameter. In same specimen ninety-eight per cent of the grains consisted of white quartz. 'The remainder consisted ur quartz of an amethyst pink color, bright green grains, and some dark quartz. Some spherical grains of lime carbonate were also observed, and resembled oolotic spherules ............ 12

VII. SECTION IN THE SOUTH BLUFF OF THE NORTH BRANCH OF WALNUT CREEK NEAR THE SOUTHWEST CORNER OF SEC. 23, PENN TOWNSHIP.

3. (4) Grayish white limestone in thin ledges...... 3

2. (4) Grayish white limestone in a single solid ledge, with curving flattened stems resembling fucoids impressed into the upper surface. It contains, especially near its lower surface, Pugnax ottumwa White, Seminula trinuclea Hall, and Spirifer keokuk Hall. 21/2

1. (4) A thin seam of shaly material containing Pugnax ottumioa White, in abundance...

VIII. SECTION IN THE NORTH BANR OF THE MIDDLE BRANCH OF WALNUT CREER IN THE NE. $1 / 4$ OF THE SE. $\$$ OF SEC, 21 , PENN TOWNSHIP.

(4) Grayish white limestone with some seams of shale contalning Pugnax ottumwa White, $P$. grosvenori Hall, Seminula trinuclea Hall, Bpirifer keokuk Hall, Deltodopsis stludovici St. J. and W. (?) ............ 6

Sections on Rocky Branch.-On Rocky branch, which is a tributary to Walnut creek and comes in from the west, following the south boundaries of Penn and Walnut townships, rock exposures are frequent and the same succession is seen except that the lower dolomitic beds do not come into view. The sandy ledges occur farthest down and appear as far up as in the northeast quarter of section 6 in Lockridge township. The upper marls and regularly bedded limestones appear in section 36 in Penn township and in section 1 in Buchanan township. Only a few of the local details can be given. 
IX. SECTION IN THE SOUTH BLUFF OF ROCKY BRANCH, IN THE NW. 1/4 CF THE NW. $/ 4$ OF SEC. 3, LOCKRIDGE TOWNSHIP.

FEET.

4. (3) White, somewhat brecciated limestone with . cakes of yellow chert (not well exposed).. 5

3. (3) Marly band with a small and almost spheroidal seminula $\ldots \ldots \ldots \ldots \ldots \ldots \ldots \ldots \ldots$

2. (3) Brecciated, light-colored limestone (imperfectly exposed) $\ldots \ldots \ldots \ldots \ldots \ldots \ldots \ldots \ldots, 6$

1. (2) Cross-bedded and variable mortar-rock and limestone ....................... 30

X. SECTION IN THE BED OF A RAVINE GOING SOUTH INTO ROCKY BRANCH IN THE SW, 3/4 OF THE SE. 1/4 OF SEC. 32, WALNUT TOWNSHIP.

4. (?) Brecciated white limestone in a solid ledge, which is fossiliferous below............ 3

3. (3) Greenish marl with fossils which are deformed, mostly Pugnax ........... $1 / 2$

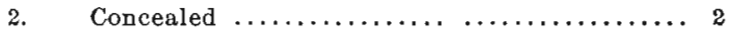

1. (2 and 3 ) Jaminated sandstone changing into limestone above ................ $21 / 2$

XI. SECTION UNDER THE BASE OF THE WEST BLUFF OF A SOUTH TRIBUTARY TO ROCKY BRANCH IN THE NE. 1/4 OF THE NW. $1 / 4$ OF SEC. 8, LOCKRIDGE TOWNSHIP. [MONSON'S QUARRY.]

5. (3 or 4) Fine-grained, compact limestone of almost lithographic texture, and containing small spherical aggregarates of pyrites.. 11/3

4. (3 or 4 ) Soft, gray limestone in thin courses... 2

3. (3 or 4) Gray limestone in a single ledge...... $21 / 4$

2. (3) Dark gray, compact and slightly bituminous limestone, which is unequally affected by acids' taken from different spots, being dolomitic in some places and calcareous elsewhere. A hand specimen was seen to be made up of a compact aggregate of somewhat obscurely limited, fine particles of varied shape, some being organic fragments and some appearing like accretions of a calcareous precipitate $\ldots \ldots \ldots \ldots \ldots \ldots \ldots \ldots 1 / 2$

1. (3) Blue shaly marl, exposed $\ldots \ldots \ldots \ldots \ldots \ldots \ldots 1 / 4$

Sections on Turkey Creek and adjacent Ravines. - In the northeastern part of Lockridge township the Saint Louis rocks have their greatest vertical development in this county. This region drains into Skunk river, whose channel lies nearly 200 feet below the highest adjacent uplands, and the smaller streams afford several deep and comparatively narrow valleys exposing the bed 
rock. In "Cedar Bluff,", on the west bank of Skunk river and at the north line of section 13 in Lockridge township, all the divisions in the preceding sections, except the uppermost, appear in succession. They show the effects of weathering and of leaching by the underground water. Occasionally there are indications of small, ancient cavernous openings which have been partly filled and collapsed, causing local brecciation. In a small ravine in the southeast quarter of section 24 in Lockridge township two large crystalline masses of Iceland spar lay near a small exposure of limestone, in which several fissures filled with the same mineral were noted. One of these masses was sixteen inches in diameter. The following sections are typical of the region:

XII. SECTION IN P. W. LYON'S QUARRY IN THE NORTH BANK OF TURKEY CREEK NEAR THE CENTER OF THE NE, Y/4 OF SEC. II, LOCKRIDGE TOWNSHIP.

9. (3) Compact, grayish white limestone, considerably weathered $\ldots \ldots \ldots \ldots \ldots \ldots \ldots \ldots, 1$

8. (3) Yellowish gray marl, with more solid calcareous lumps $\ldots \ldots \ldots \ldots \ldots \ldots \ldots \ldots \ldots, 2$

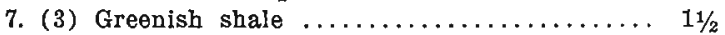

6. (3) Breccia of sandy, yellow marl with angular lumps of limestone of fine lithographic texture and round concretions of less fine texture. This breccia is overlain by a continuous layer of laminated limestone. The round concretions have a brecciated structure, showing fragments of varied texture and some fine branching joints, which have been healed by infiltration. The laminated layer which overlies contains a very few small grains of quartz and is itself composed of an aggregation of small grains or lumps or compact calcareous material. These lie closely appressed and are in some places flattened, as if by pressure in a vertical direction. Some minute stylolithic joints are seen, and there are a few very smail imbedded shells of a brachiopod .............. 5

5. (3) Greenish gray clay $\ldots \ldots \ldots \ldots \ldots \ldots \ldots \ldots 2$

4. (2) Yellow limestone $\ldots \ldots \ldots \ldots \ldots \ldots \ldots \ldots, 1$

3. (2) Greenish, shaly marl $\ldots \ldots \ldots \ldots \ldots \ldots \ldots 1 / 4$

2. (2) Mortar.rock, changing downward into a more pure sandstone. The upper part is brownish in color and the cement in 
which the sand lies is partly dolomitic. In one hand specimen, which was carefully examined the quartz grains were from one-eighth to two millimeters in diameter. The grains exceeding one millimeter were very generally rounded, while those below this size were mostly angular. Mica occurred sparsely. Joints of crinoid stems and some tubes of a bryozoan were noted. Another specimen from the base of this ledge was a fine-grained and friable sandstone with a sparse and wholly dolomitic cementing matrix. The sand grains were mostly from one-half to onefourth millimeters in diameter. Mica was present, but sparse ...............

1. (2) Obliquely bedded mortar-rock consisting of about one-third of its bulk of arenaceous material, with occasional lumps of clay and with some interbedded thin seams of bare matrix without sand. The bulk of the sand in one hand specimen, consisted of grains from one-fourth to one-half millimeters in diameter, quite generally rounded. The material represented was in the main translucent quartz. Some of the grains were light colored and lark chert, and a few mica quartz scales. Joints of crinoid stems and tubes of some bryozoa were also found. The cementing material was seen to be of variable abundance along different bedding planes, and some of it effervesced readily and some tardily under the action of acids. The slow effervescence was particularly noticeable along some bluish gray and compact layers, which were interlaminated with the otherwise porous and coarsetextured bulk of the rock. The surface of this ledge was covered with a white efflorescence of magnesium sulphate..... 11

XIII. SECTION IN THE SOUTH BANK OF TURKEY CREEK, THIRTY RODS NOKTH. WEST OF THE SOUTHWEST CORNER OF SEC. IO, LOCKRIDGE TOWNSHIP.

FEET.

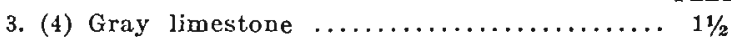

2. (3) Shaly marl with Seminula $\ldots \ldots \ldots \ldots \ldots$ 1/2

1. (3) Limestone, marly below ............ $4 \frac{1 / 2}{2}$ 
XIV. SECTION IN "CEDAR BIUFF" AT THE MOUTH OF RATILESNAKE CREEK, ONE-FOURTH MILE EAST OF THE SOUTHWES I CORNER OF SEC, 12, LOCKRIDGE TOWNSHIP.

22. (4) Somewhat brecciated but otherwise compact grayish white limestone $\ldots \ldots \ldots \ldots \ldots \ldots, 2$

21. (4) Green shaly material ............... 1

20. (4) Brecciated gray limestone ............ 1

19. (1) Thinly laminated stony calcareous material $1 / 3$

18. (4) Brecciated and in part laminated gray lime-

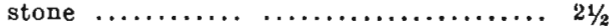

17. (4) Seam of shaly material $\ldots \ldots \ldots \ldots \ldots \ldots \ldots 1 / 4$

16. (4) Brecciated gray limestone .............. 1\%,

15. (3) Shaly marl with some concretions of calcareous material and a small, almost sphertcal form of Seminula ................

14. (3) White, Incipiently brecciated limestone, with stylolithic joints along some seams A hand specimen was seen to be a compact rock filled with minute organic fragments mostly so small as to fall short of observation by the unaided eye. It also contained occasional minute oolitic spherules ..... 6

13. (3) Dull grayish yellow limestone .......... 2

12. (3) Yellow shaly marl $\ldots \ldots \ldots \ldots \ldots \ldots \ldots \ldots, 5$

11. (3) Massive beds of soft, earthy, greenish limestone weathering into spheroidal masses with more thoroughly weathered material between. A hand specimen was seen to be of a fine and uniform texture, with some faintly marked bedding planes. When crushed and examined under the microscope the almost entire mass was seen to consist of exceedingly small rhombohedral crystals, which effervesced slowly with acids (dolomite) ............... 3

11. (3) Same as above, but more soft ......... 2

2. (3) Soft and earthy mortar-rock, consisting of about one-half sand and the other half being a calcareous magnesian matrix. The bulk of the sand grains are from onefourth to one-half of a millimeter in diameter, but range up to one millimeter. The finest sand is mostly angular but the coarse grains are well rounded .........'

8. (3) Shaly marl, containing fragments and lumps

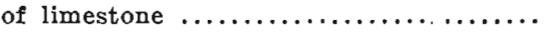

7. (2) Grayish yellow and soft dolomitic rock with an irregular bedding of a concretionary 
appearance, and containing specks of a green clayey material. It is in places a fine-grained dolomite, containing a few, mostly angular, quartz grains imbedded. In other places it has a coarser texture. The clastic elements consist of quartz grains, colorless, white, dark, or purplish red, with some mica scales, and some rounded dolomitic aggregations. The largest grains are rounded and some were seen to have concavities on their surfaces which appeared to be produced by solution $\ldots \ldots \ldots \ldots \ldots \ldots \ldots \ldots \ldots \ldots . . \ldots \ldots \ldots$

6. (2) Greenish, and yellowish gray, shaly marl (not fully exposed) ............. s

5. (2) Gray and yellow sandstone. It is friable, fine, and slightly micaceous with a sparse dolomitic cement of variable copiousness along different bedding planes. The sand grains in a hand specimen were mostly angular and fell mainly between one fourth and one half millimeter in diameter. Some few were of an intensely green color and some yellow and olive colored. Mica was present, and some of the grains had an etched surface ...............

4. (1) Gray or yellowish, somewhat dolomitic limestone of fine texture. In a ground specimen it is seen to be porous, and shows a faintly brecciated structure. It is traversed by small, gently flexuous fissures of uniform width, which are filled with clear crystalline calcite $\ldots \ldots \ldots \ldots \ldots \ldots 3$

3. (1) Greenish, shaly, soft, and micaceous sand-

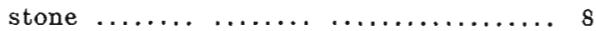

2. (1) Yellow, soft dolomite. In a hand specimen it was seen to be fine-grained and minvitely porous, with small irregrular greenish lentils of more clayey material throughout. 'These lie parallel witl the bedding planes ....................

1. (1) Bluish, gray, dolomitic, and shaly marl with a few very sparsely disseminated small siliceous grains. It contains occasional organic fragments, such as joints or crinoid stems, and tubes of bryozoa, and some spheroidal solid quartz geodes of irregular shape..$\ldots \ldots \ldots \ldots \ldots \ldots \ldots \ldots$. 
XV. SECTION IN THE WEST BANK OF A RAVINE RUNNING NORTH INTO RATTLESNAKE CREEK, NEAR THE CENTER OF THE NE. $1 / \%$ OF THE NE. $1 / 4$ OF SEC. 14. LOCKRIDGE TOWNSHIP.

6. (3) Decayed, fine-grained, yellow limestone very much disintegrated above ............ 3

5. (?) Yellow marl with some blue shale ....... 4

4. (?) Decayed limestone with some sand rock... 2

3. (2) Band of yellow marl with a black ferruginous seam above $\ldots \ldots \ldots \ldots \ldots \ldots \ldots, 1 / 2$

2. (2) Cross-bedded mortar-rock ............. 5

1. (2) Laminated mortar-rock consisting of about one-half sand and one-half calcareous cement. The sand grains are mostly rounded and range from one-fourth to two millimeters in diameter. Nine-tenths are common translucent quartz and the remalnder are chert, dark quartz, pink quartz and a few green grains $\ldots \ldots \ldots \ldots \ldots \ldots \ldots$.

EET.

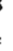
2 5 1

XVI. SECTION IN THE SOUTH BANK OF A CREEK, A LITTLE WEST OF THE CEN TER OF THE NORTH LINE OF SEC. 24, LOCKRIDGE TOWNSHIP.

3. (4) Grayish white limestone, slightly brecciated 9

2. (3) Clayey marl, containing a Seminula of spherical form and having small calcareous concretions of irregular, flattened, spheroidal shape and concentric laminated structure. Some contain a white calcareous flour in irregular pockets in the center, and one was seen to have its outer surface studded with very small shells of Seminula? (young) and Leperditia car-

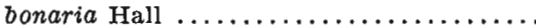

1. (3) Brecciated and irregularly bedded limestone becoming sandy below and containing imbedded specimens of Lithostrotion canadense Cast. .................. 10

XVII. SECTION IN THE SOUTH BANK OF BRUSH CREEK, NEAR THE NORTHEAST CORNER OF SEC. 36, LOCKRIDGE TOWNSHIP.

5. A seam of limonitic material marking the unconformity with the Coal Measures..

4. (4) Gray marl, shaly above, and with some stony FEET. and more calcareous bands near the middle. This contains Fenestella serratula Uhlr., Productus ovatus Hall, Pugnax ottumwa White, Seminula trinuclea Hall, Spirifer keokuk Hall, Anisotrypa fistulata Uhlr., Spirorbis sp., Zaphrentts pallaensis Worthen $\ldots, \ldots, \ldots, \ldots, \ldots, \ldots, \ldots$, i 
FEET.

3. (4) Gray limestone in sound ledges, containing frequent cubic crystals of pyrites .... ?

2. (4) Gray limestone with the upper surface of the ledge bearing occasional fucoid flattened curving stems some six inches in length and an inch in widest diameter... 1

1. (4) Gray limestone with upper surface of the ledge frequently studded with such fossils as Spirifer keokuk Hall, Pugnax ottumwa White Allorisma, sp., Productus, sp. and stems of crinoids $\ldots \ldots \ldots \ldots \ldots \ldots \ldots$.

About a quarter of a mile farther up this creek the underlying sandy ledges are seen in the left bank, and above this place the fossil-bearing limestone ledges are again exposed at intervals, disappearing under the drift about half a mile from the east boundary of the county. Above this place only two small and widely separated occurrences of the Saint Louis beds were observed in this stream. One of these has been quarried. It is located in the northeast quarter of the northwest quarter of section 28 in Lockridge township. The other locality is in the south bank of the creek in the west half of the southeast quarter of section 10 in Buchanan township. In both of these places the ledges which are exposed belong to the upper fossil-bearing division of this formation.

On Wolf creek only one exposure was noted, and this was quite small and belonged to the same horizon, as seen from the following:

XVIII SECTION IN THE BED OF WOLF CREEK, SUUTH OF THE CENTER OF SEC5, ROUND PRAIRIE TUWNSHIP.

FEET.

2. (4) Light gray marl with joints of crinoid stems, lamellibranchs, small cyathophylloids, Anisotrypa fistulata Uhlr., F'enestella serratula Uhlr., Phillipsia (?pygidium), Eumetria marcyi Shumard, Derbya keokuk Hall, Pentremites koninkiana Hall, Productus ovatus Hall, Seminula trinuclea Hall, Pugnax ottumwa White, $P$. grosvenori Hall, Cleiothyris roissyi L'Evellle, Spirifer keokuk Hall, Dielasma formosa Hall, Pinna (? fragment) $\ldots \ldots \ldots \ldots \ldots$.

1. (4) Gray limestone with some fossils ........ 2 
Sections in the Cedar Creek Basin.-In the drainage basin of Cedar creek the Saint Louis is best exposed on the main stream. A thickness of nearly sixty feet can be made out and this includes the two upper divisions seen in the Skunk river drainage basin. From south of the center of section 35 in Round Prairie township to the west line of section 36 in Cedar township the outcrops are almost continuous in the banks of the Cedar creek, and after an interruption of one-half a mile of Coal Measure rocks it continues two and a half miles farther up the creek. Above this there are only two other points at which it rises above the creek, one in the northeast quarter of section 24 and another somewhat larger area in sections 9,10 and 15 in Liberty township. West of here it has not been observed. Most of the tributaries from the south in Cedar and Round Prairie townships cut down into this limestone as far as their courses run in this county, but in the affluents from the north it is seen only in Rock creek, where it appears for two miles. The following sections will sufficiently illustrate its character in this region:

XIX. SECTION IN THE BANK OF CEDAR CREEK IN THE SW. $3 / 4$ OF THE SE. $1 / 4$ OF SEC. 34, ROUND PRAIRIE TOWNSHIP.

5. (4) Gray marl containing Pugnax ottumwa White, Productus sp., Seminula trinuclea Hall, and some rhizopods ........... 2

4. (4) White limestone with one ledge of very fine, almost lithographic texture. A ground specimen of the latter was seen to contain scattered imbedded fragments of small brachiopods and dispersed minute crystals of pyrites $\ldots \ldots \ldots \ldots \ldots \ldots \ldots, 2$

3. (4) Gray limestone of ordinary texture, in ledges varying from six inches to one foot in thickness. A shaly seam near the middle was studded with Pugnax ottumwa White:................ 5

2. Not seen here. (What follows is exposed about fifteen rods farther south in the bed and the banks of the "cut-off" which the creek is making in leaving the oxbow).. 30 (?)

1. (3) Gray, arenaceous limestone changing downward into softer, yellow, dolomitic rock. The ledges are flexed and fractured and in places brecciated. In the middle part of the exposure there is a discontinuous 
layer of breccia, about a foot thick, which is partly silicified and has a very rough exterior. At about the same level silicified specimens of Lithostrotion canadense Cast. occur and below this the rock contains smooth loaves and balls of a yellow or gray chert, which contains frequent casts of brachiopods, such as Derbya keokuk Hall, Spirifer littoni Swallow and Pugnax grosvenori Hall. Associated with these chert balls and also occurring in small crevices in the surrounding rock is a dark green earthy clay containing aluminum, iron, and a trace of chromium. The same ledges have crevices which contain some very clear crystals of Iceland spar. These are stained green by the same earthy material. One fractured ledge in the lower part of the exposure consists of a fine-textured and minutely porous limestone which contains indistinct fragments of shells. This is cut by some very thin fissures filled with limonite $\ldots \ldots \ldots \ldots \ldots \ldots \ldots \ldots . \ldots 10$

$X X$. SECTION IN THE NORTH BANK OF CEDAR CREEK, EAST OF THE SOUTHWEST CORNER OF SEC. 34, ROUND PRAIRIE TOWNSHIP,

6. (3 and 4 ?) Solid ledges of gray, partly brecciat-, ed limestone with some layers of shaly marl .......................20

5. (3) Marly dolomitic material ............ 3

4. (3) A more or less discontinuous ledge of cherty gray or dark quartz showing a peculiar brecciated structure ......... 2

3. (3) Yellow or gray, soft limestone, occasionally dolomitic and often with some imbedded sand and lumps of brecciated siliceous material. In places it is coarsely brecciated and in other places it contains thin layers of fine-textured dolomitic rock with minute lentils of Lithostrotion canadense Cast. .............

2. (3) Pure calcareous limestone with a Seminula and occasional balls or loaves of chert with casts of other brachiopods. Some small fissures in this ledge, evidently due to incipient brecciation, were observed to be filled with arenaceous material ..... 11 
FEET.

1. (3) Light gray, greenish marly shale with thin layers of pure calcareous rock. Other layers are slightly dolomitic and are in places cut by very thin fissures healed with crystalline calcite

XXI. SECTION IN THE SOUTH BANK OF ROCK CREEK IN THE NE. $3 / 4$ OF THE NE. 1/4 OF SEC. 32, ROUND PRAIRIE TOWNSHIP.

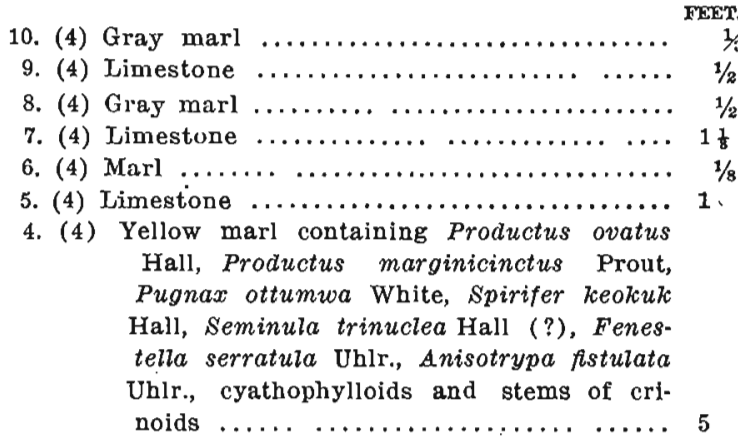

3. (4) Limestone ....................... 1

2. (4) Marl with some of the same fassils as those above ........................... $1 / 8$

1. (4) Quite evenly bedded ledges of bluish gray

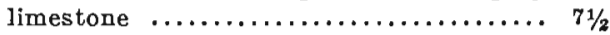

XXII. SECTION IN A RAVINE ABOUT ONE-SIXTH MILE SOUTHWEST OF THE LEN TER OF SEC. 23, ROUND PRAIRIE TOWNSHIP.

6. (4) Solid grayish white limestone on the upper surface of which were noted Pugnax ottumwa White, Spirifer littoni Swallow, Dielasma formosa Hall, D. turgida Hall, and a small lamellibranch ........... 5

5. (3) Shaly and impure limestone............ 5

4. (3) Jimestone disintegrating into thard and thin layers $\ldots \ldots \ldots \ldots \ldots \ldots \ldots \ldots \ldots \ldots \ldots \ldots, 41 / 2$

3. (3) Arenaceous shale..$\ldots \ldots \ldots \ldots \ldots \ldots \ldots \ldots .2$

2. (3) Irreguarly bedded gray or blue soft rock... 4

1. (2) Cross-bedded mortar-rock with some shaly beds $\ldots \ldots \ldots \ldots \ldots \ldots \ldots \ldots \ldots \ldots \ldots 20$ 
XXIII. SECTION IN THE SOUTH BANK OF CEDAR CREEK IN THE NE. $\%$ OF SEC, 34. CEDAR TOWNSHIY.

5. (4) Grayish white limestone.............. 4

4. (4) Marly limestone with two bands of more solid stony material near the middle. This contained Productus marginicinctus Prout., $P$. ovatus Hall, Pugnax ottumwa White, Spirifer keokuk Hall, Seminula trinuclea Hall, Zaphrentis pallaensis Worthen, Anisotrypa fistulata UhIr., and Allorisma

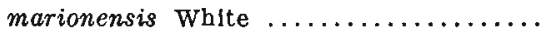

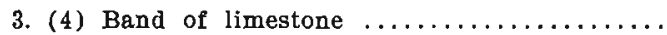

2. (4) Seam of shale sharply marked off above and below $\ldots \ldots \ldots \ldots \ldots \ldots \ldots \ldots$

4

\section{7}

4

1. (4) Grayish white limestone, the upper ledges having a fine texture and being bedded in straight courses of uniform thickness... $6 \frac{1}{2}$

XXIV. SECTION IN AN OLD QUARRY IN THE EAST BANK OF CEDAR CREEK NORTHEAST OF THE CENTER OF SEC. 10, LIBERTY TOWNSHIP.

6. Pockets of green shale belonging to the Coal Measures.

5. (4) Gray limestone weathering into round bowlders, in places with small crevices flled with calcite. Fragments of crinoid stems and brachiopod shells are common....... 4

4. (4) Light-colored marl with occasional stony concretions. This marl contains Cleiothyris roissyi L'Eveille, Derbya keokuk Hall, Productus ovatus Hall, P. marginicintus Prout., Seminula trinuclea Hall, Spirifer keokuk Hall, Lithophaga pertenuis M. \& W. (?), various small cyathophyllolds, stems of crinoids, small plates of an Archæocidaris, Endothyra baileyi Hall, Cytherellina glandella Whitfield, Leperditia carbonaria Hall and minute calcareous spines of various forms........... 2

3. (4) Gray limestone $\ldots \ldots \ldots \ldots \ldots \ldots \ldots . \ldots \ldots$

2. (4) Marl with most of the same fossils as were found in number $4 \ldots \ldots \ldots \ldots \ldots \ldots \ldots \ldots 3$

1. (4) Gray limestone containing occasional crystals of pyrites $. . \ldots \ldots \ldots \ldots \ldots \ldots \ldots \ldots \ldots, 3$ 
XXV, SECTION NEAR THE CHICAGO, ROCK ISLAND \& PACIFIC RAILROAD IN THE NW. $1 / 6$ OF THE SE. $1 / 4$ OF SEC. 9, LIBERTY T OWNSHIY.

2. (4) Grayish white marl containing many fossils

FEET. such as Cleiothyris roissyi L'Eveille, Der. bya keokuk Hall (?), Productus ovatus Hall, Pugnax ottumwa White, P. grosvenori Hall, Șeminula trinuclea Hall, Spirifer keokuk Hall, Allorisma marionensis White, some cyathophylloids, some bryozoa, stems of crinoids, and some rhizopods $. . . \ldots \ldots \ldots \ldots \ldots \ldots \ldots \ldots \ldots . \ldots \ldots$.

1. (4) Grayish white limestone in heary ledges, containing some pf the same fossils that were found in the marlabove. A polished hand specimen was seen to have occasional small crevices filled with calcite. There were also frequent imbedded fragments of stems of crinoids and shells of brachiopods. When crushed and washed it yielded some shells pf rhizopods.............

Sections in the Des Moines River Basin.-In the drainage area of the I)es Moines there are also a few places where the deepest valleys have laid bare the Saint Louis. These are in Lick creek at and near the junction of its two forks in section 30, Liberty township. Farthest south there are some brecciated and slightly arenaceous limestones and to the north of this place to the more regular bedded limestone with alternating layers of marl. We have here the same succession and no doubt the same beds as seen on Cedar creek. In the southwest quarter of the southeast quarten of section 30 an open well was in the process of being blasted out in this formation at the time of the survey. It was in the valley of the creek close to the south bluff and showed twenty feet of limestone alternating with some fine arenaceous beds below and some shale above.- The natural exposures were as follows:

XXVI. IN THE BED OF LIZK CREEK NEAR THE CENTER OF SEC. 25, DES MOINES TOWNSHIP.

2. (4) Stony marl containing Seminuta trinuclea Hall, Pugnax ottumwa White, Productus sp., Pinna (?) (fragment), Astartella sp., (?) $\ldots \ldots \ldots \ldots \ldots \ldots \ldots \ldots \ldots \ldots \ldots \ldots \ldots$

1. (4) Solid gray limestone with some fossils...... 2 
XXVII. SECTION IN THE WEST BANK OF THE EAST FORK OF LICK CREEK IN THE NW. $1 / 4$ OF THE SE. $1 / 4$ OF SEC. 30, LIBERTY TOWNSHIP.

6. (4) Gray limestone $\ldots \ldots \ldots \ldots \ldots \ldots \ldots \ldots \ldots \ldots, 1$

5. (4) Gray marl with some fossils........... 2

4. (4) Gray limestone $\ldots \ldots \ldots \ldots \ldots \ldots \ldots \ldots \ldots \ldots . \ldots \ldots$

3. (4) Gray marl with occasional fossils......... 2

2. (4) Heavy ledges of gray limestone.......... 4

1. (3) Limeston.e, occasionally brecciated........ 9

STRATIGRAPHY.

In the forggoing sections an attempt has been made to refer the respective numbers which have been described to one of the four divisions into which the Saint Louis strata can be divided in this region. These divisions have been indicated for each member by figures in brackets. They correspond, in the main, to the divisions previously made out for the Saint Louis in Washington county by Bain, and which will here be designated by names essentially as proposed by him, viz:

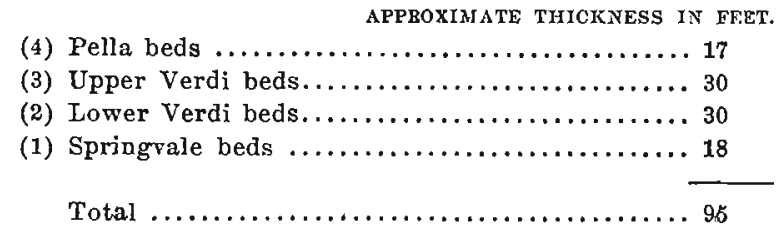

The Verdi beds have been separated into an upper and a lower division. It is quite probable that neither the lowermost part of the Springvale beds, which make the base of the section, nor the uppermost part of the Upper Pella beds, which constitutes the top of the formation, are seen in this county. It is therefore likely that the Saint Louis exceeds in thickness the ninety-five feet which appear in this county. A brief general description may now be given of each of the four divisions.

The Springvale Beds.-These consist of soft dolomitic limestones interbedded with dolomitic marly shales and some sandstone of fine texture. The dolomite consists of an aggregate of crystals of minute but varying sizes. It frequently contains small lentils of green clayey material, is here and there traversed by thin and curving fractures which have been filled with clear crystalline calcite and occasionally contains a small admixture 
of fine sand. With the aid of a hand lens some minute straight tubules are commonly seen in these ledges. The shaly beds are often marly and dolomitic. . Some are apparently disintegrated and leached dolomite. The more clayey beds contain solid spheroidal concretions of chalcedonic quartz, measuring from two to eight inches in diameter and resembling geodes in form. In the limestones, impressions or imperfectly preserved fossil remains were noted representing stems of crinoids, a species of a Productus, and Hemitrypa frontana Uhlr.

The Lower Verdi Beds.-Above the magnesian limestones and shales just described, there is usually some exceedingly variable material most of which might be called mortar-rock as it consists of sand cemented together by a calcareous or magnesian matrix. The sand may be fine or coarse, the matrix may be calcareous or dolomitic, and the ratio between the sand and the matrix may vary to the exclusion of either one of the two, when there is pure sandstone on the one hand, and pure limestone on the other. By the increase of clayey material either of these rock varieties may become shaly. The limestones are hard and compact, or marly. The mortar-rock and the sandstones may be regularly bedded, or they may be most diversely cross-bedded. Frequently the alternating thin seams have an unequal amount of matrix and sand.

- Finally, any of these variations and sediments may be brecciated and mingled with each other promiscuously. Dolomitic layers are apt to exhibit occasional thin fissures filled with crystalline calcite. The arenaceous material ranges in the sizes of the grains from pebbles half an inch in diameter, which are rare, to the finest discernible particles. It is usually well sorted for each layer, and all the medium sized grains are well rounded. Ninety-five per cent, if not more, consist of clear white quartz. The remainder is mica, a few pink, purple, and green grains among the finest materials, and some chert and some calcareous fragments among the largest pebbles. At one place there was seen in a coarse and very sandy mortar-rock of this division some curving tubular cavities in the sand (section VI). These are filled with calcite so as to màke the rock perfectly compact and they presented an appearance which suggested an organic agency, as if produced by some boring animal. At several other places there 
were noted small and single joints of crinoid stems. A bryozoan or a coral, somewhat like a Monticutipora and consisting of closely appressed and nearly parallel tubes, which were quite fragile and poorly preserved, was seen in several places in the mortarrock, associated with crinoid joints.

The Upper Verdi $\bar{b} e d s$. -The arenaceous members just described change upward into brecciated, less sandy, and less frequently dolomitic limestone. At this horizon there are some very fine-grained calcareous ledges, in which lie imbedded fragments of thin brachiopod shells, and occasional oolitic spherules. The siliceous material is often gathered into concretionary. masses, sometimes of great size. There are silicified corals, and nodules of chert containing moulds of brachiopod shells. In the valley of Cedar creek large lenses of a tough gray or almost black quartz of a peculiar brecciated structure, as if depesited by infiltration along closely intersecting joints, are seen replacing parts of certain ledges (Fig. 60). One of these masses was six feet wide and two feet thick near the middle, having a hemispherical shape with the convex side up. Several fossils occur at this horizon, viz:

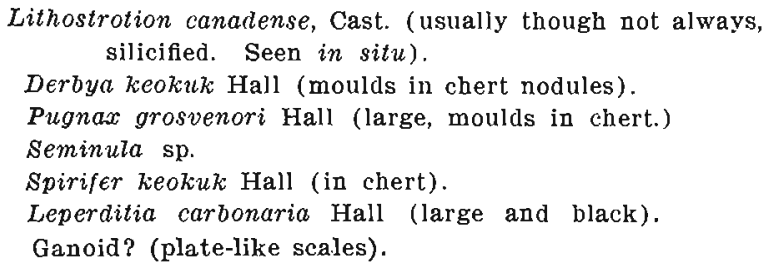

In the creeks draining into Skunk river there occurs near the top of this division a shaly or marly seam, usually about six inches in thickness, which can be recognized at points several miles apart. It lies between two ledges of solid limestone, which are sometimes slightly broken or brecciated. In correlating local sections this seam serves as an important landmark, and therefore deserves special attention here. It is number 2 of section $V$, number 3 of section IX, number 2 of section XIII, number 15 of section XIV, and number 2 of section XVI. It is also seen east of the wagon road in the north bluff of Rocky branch near the northwest corner of section 3, Lockridge township, and near a 
spring west of the wagon road in a small tributary to Walnut creek from the north, near the center of the southwest quarter of the sonthwest quarter of section 21 , Walnut township. This layer contains invariably and in profusion a Seminula with very conver valves and of small size, so as to be of the size and shape of a pea. The valves are frequently dissolved away, leaving a mere

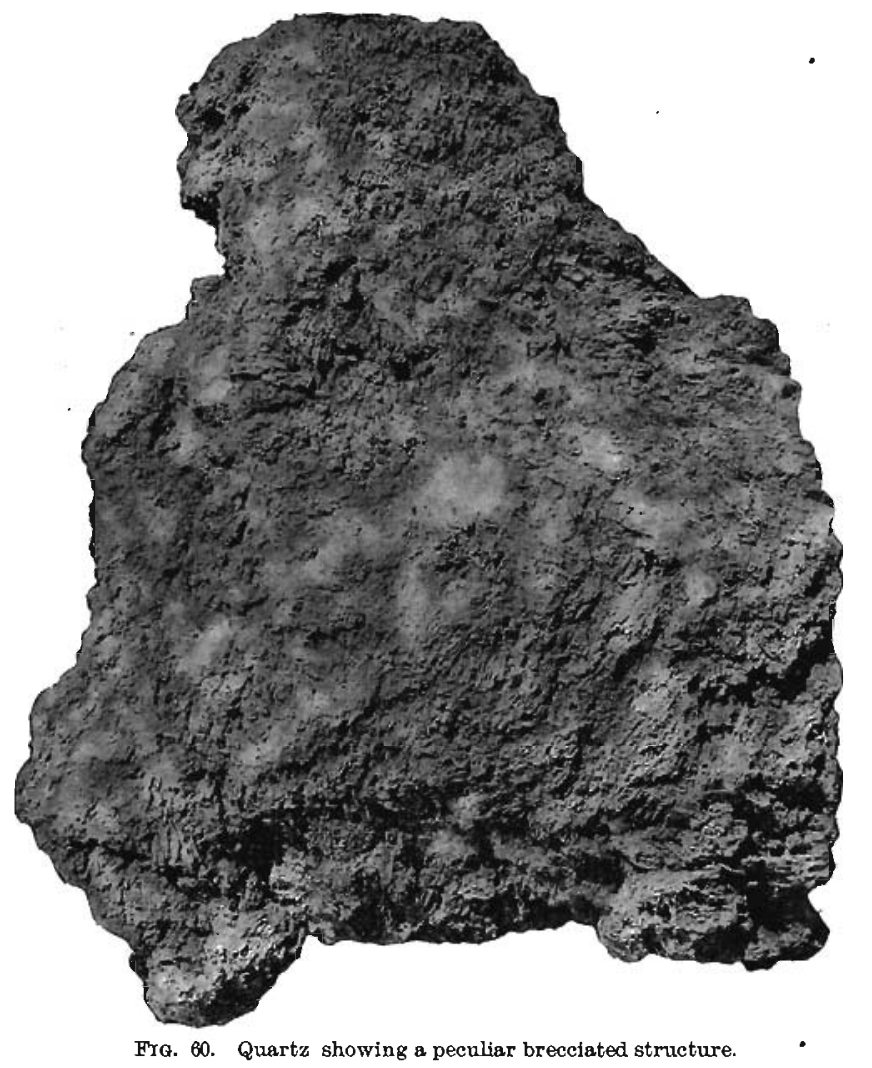

calcareous kernel, in which the spirals of the fossil sometimes appear. At other places these shells may be cavered by an enveloping calcareous crust, and simulate roughly shaped pisioliths. Associated with these shells there are calcareous concretions or balls, usually slightly flattened and about an inch in diam- 
eter. In the interior of these there are irregular pockets of a white calcareous flour. The seam may be said to consist of these concretions and of the small Seminula shells, imbeddeed in a shaly or marly sparse matrix. On the surface of one of these concretions were noted some minute brachiopods and Leperditia carbonaria Hall. Occasionally a part of the bed consists of lumps of fine oolitic limestone. The Seminula is regarded by Schuchert as being an undetermined species different from Seminula trinuclea Hall, which occurs in the Pella beds farther up in the section. In several places springs issue from the ground two or three feet below this shaly seam.

The Pella Beds.-These consist mostly of heavy-bedded ledges of compact, calcareous limestone, alternating, especially above, with seams of greenish marly shales. Occasionally the limestone is slightly broken up and brecciated. Some ledges have a very fine rexture. Were it not for the presence of bits of fossils, and crystals or irregularly shaped grains of pyrites these ledges might be called lithographic limestone. The pyrites is usually in cubic crystals, about an eighth of an inch in diameter. The shales or marls are sometimes quite hard and stony. Fossils are common in the limestones and quite abundant in the marls, consisting of a few species of brachiopods, lamellibranchs, cyathphylloids, bryozoa, ostracods and rhizopods. The latter occur both in the limestone and in the marls. A list of the fossils observed by the autlior is here given. The appended figures indicate the number of localities at which each species has been noted.

Endothyra baileyi Hall, 5.

Other rhizopods, not identified, 4.

Zaphrentis pellaensis Worthen, 8.

Pentremites koninckiana Hall, 1.

Archaeocidaris (spines and separate plates, small), 2.

Crinoids (stems), 10.

Spirorbis (?), 1.

Anisotrypa fistulosa Ublr., 6 .

Fenestella serratula Uhlr, 3.

Cteiothyris roissyi L'Eveille, 8.

Derbya keokuk Hall, 4.

Dielasma formosa Hall, 2.

Dielasma turgida Hall, 1.

Eumetria marcyi Schumard, 1.

Productus marginicinctus Prout, 3.

Productus ovatus Hall, 6. 


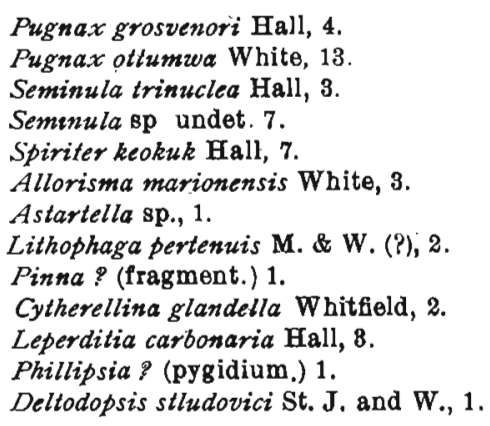

The Springvale beds and the Pella beds were evidently deposited some distance off shore in comparatively deep and quiet waters. Individual beds persist for considerable distances, especially in the latter. The presence of rhizopod shells in these also points to the correctness of this view. With regard to the Verdi beds, it has been supposed that the presence of sand, often crossbedded, and the brecciated character, especially prominent in the Upper Verdi, should indicate littoral conditions of deposition. Against this view is the general absence of plant remains and the frequent presence of crinoid stems. The writer would remind readers interested in this question, that sand quite as coarse as that in the Verdi beds is found associated with crinoid stems in deposits now forming on the outer slope of the continental shelf in the Atlantic ocean, at depths exceeding 3,000 feet. This sand is always well worn and is apparently moved by bottom currents. It seems that such currents may very well produce cross-bedded deposits. And why not also cause brecciation in yet plastic rocks by local erosion and settling? The persistence of one thin seam of marl over many miles of territory testifies at any rate to off shore conditions during the latter part of the Verdi stage.

But little need be said on the subject of the correlation of these deposits with the Lower Carboniferous divisions elsewhere. The clays of the Springvale beds resemble those of the Keokuk in having geode-like concretions, but they differ from them most markedly in their lack of fossils and in their dolomitic character. Possibly their dolomitization was the cause of the destruction of their fossil remains, and they may be an attenuated equivalent of the Keokuk-formation. There is no decisive evidence on this 
point. Here, as in Washington county," there are no sharp limits to be drawn between any of the members of the Saint Louis as above described. They all merge into each other by slow gradations in composition, bedding and structure.

THE DES MOINES.

By far the greater part of the area of the county is covered by the base of the Coal Measures, usually known as the Des Moines. These beds overlie the eroded and uneven surface of the Saint Louis formation everywhere, except some tracts of uncertain extent along the north boundary of the county and some comparatively narrow strips of land in the valleys of the principal streams where the underlying Saint Louis has been laid bare and appears as already described. The Des Moines consists of shales and sandstone with seams of limestone and coal and range from a few to at least 150 feet in thickness.

Walnut Tounship.-Over the northeast part of this township the Des Moines has been mostly removed by erosion, for it is only rarely seen. In sections 1 and 2 the valley which is followed by the Towa Central railroad exposes small outliers of the Des Moines, mostly sandstone. Other instances of small outliers were noted in Burr Oak creek, near the center of the west line of section 15; in a ravine near the southwest corner of section 11 ; in a creek in the southwest quarter of the southwest quarter of section 12 (where it consists of yellow sandstone with imprints of lepidodendron and with imbedded pieces of charcoal); in the road following the east line of the southeast quarter of section 14 ; to the east of Walnut creek, in the northeast quarter of the northwest quarter of section 28 (here consisting of shales); in the north bank of Rocky Branch near the southwest corner of section 34 (also shale). Aside from these occurrences dark shale. no doubt belonging to the Coal Measures, have been encountered in some wells on the uplands, as in the northeast quarter of section 34, and in the south half of section 14. As most of these observations are on the lowlands, where erosion has been most extensive, there is no doubt that the Des Moines underlies the drift on considerable tracts of the uplands, especially to the southwest.

* Bain; lowa Geol Surv., Vol. V, p. 149. 
Lockridge Township.-Here most of the uplands are evidently over]ain by the Coal Measures: In sections 4,5 and 6 small exposires are occasionally seen in the bed and the banks of Rocky Branch, and these usually consist of sandstone. In the southwest quarter of the southwest quarter of section 14 coal was for some time mined in a seam almost in immediate contact with the underlying Saint Louis marls. On. Brusho creek:Coal Measure shales are frequently and extensively exposed, and coal mines have been successfully operated for a long time. Near the north quarter post of section 29 shales and shaly sandstone of this age rise tc an elevation of thirty feet above the bed of the stream in its south bank, and near the bridge in the wagon road close by these are interbedded with:a seam of coal about fourteen inches in thickness. In section 27 there have been some of the productive mines in the county, and shales, shaly sandstone and thin seams of coal are frequently exposed in the south bank of the creek: Again, in section 36, in a run crossing the northwest corner of the section, coal has also been-mined and there is exposed a ledge of yellowish gray; hard sandstone some twelve feet in thickness and containing imprints of leaves and stems of Stigmaria. Several of the upland wetts have entered black shales and sandstones, evidently belonging to the Coal Measures.

The nature of the formation in this township is well shown in some of the explorations that have been made in connection with the mining of coal. The shaft of the mine just mentioned was only 25 feet deep. Under the surface dirt there was first some sanclsione and then dark shale, under which lay.the coal seam, in all 42 inches in thickness:- This' consisted of elght: inches of a tough cannel coal above, thirteen inches of ordinary bituminous coal, then three inches of fire clay, and below this eighteen inches of bituminous coal. The bank was worked for a couple of seasons and then abandoned on account of water. In section 27 coal has been mined for the last.forty years, and most of the coal has been removed from the entire northeast quarter of the southwest quarter of the section. The seam lies at an elevation slightly below the level of Brush creek. It has been found to be occasionally traversed by horsebacks of shaly material,.. locally known as "rolls," but these have not been of such frequency as to serious- 
ly affect the mining operations. Some faults have also been encountered. The McGregor shaft, which was located on the northwest corner of the northwest quarter of the southwest quarter of this section, and on the bottom of a south tributary of brush creek, was only a little more than fifty feet deep, going through the following section:

I. SECTION OF THE MCGREGOR COAL SHAFT.

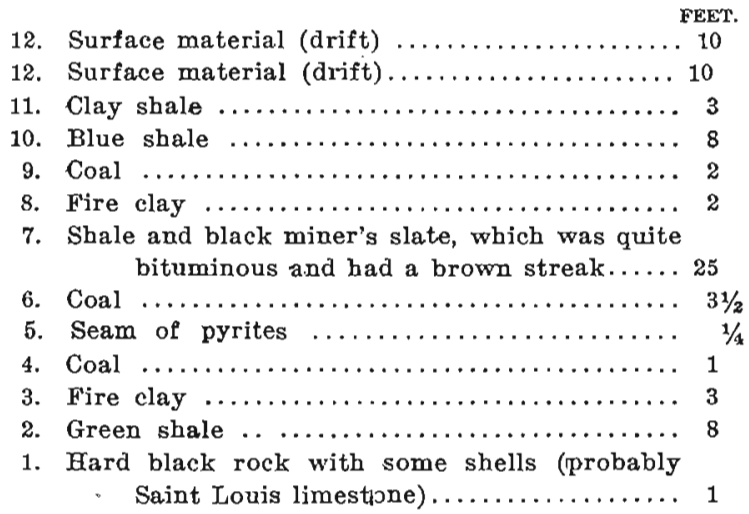

Most of the coal in this seam in the forty acre tract east of this has been mined by W. Brown \& Co. Some acres are left near the center of the section (27) and a mine is now operated on this tract by W. C. Smith Coal Company, marketing the output in Mt. Pleasant, New London, Fairfield and to the country trade. The top of this shaft is sixty feet above the bed of Brush creek and it is ninety feet deep, going through the following section:

II. SECTION OF W. G. SMITH COAL COMPANY'S SHAFT.

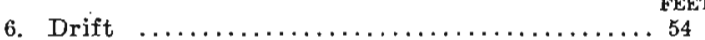

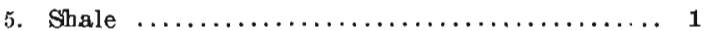

4. Yellow fire clay $\ldots \ldots \ldots \ldots \ldots \ldots \ldots \ldots \ldots \ldots, 3$

3. Black shale ...................... 9

2. Black miner's slate, containing in the basal part which forms the roof in the mine, imprints of Sigillaria leptoderma Lesq., Lepidodenaron aistans Lesq., L. aculeatum Sternb, Lepidophyllum ? (loose and separate, brown and somewhat flattened spores, scattered through the shale), and Lingula

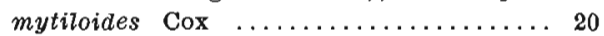

1. Coal 
The shaft was made last season and the entries were only extended a few rods, when the mine was visited by the writer. Op. erations are somewhat impeded by water, which is raised by horse power. As far as explored, the coal dips one foot in ten to the north and on the south of the shaft there is a fault with a downthrow of five feet in the same direction. The fault plane itself has a dip to the north of about $32^{\circ}$ and trends $W .15^{\circ} \mathrm{S}$.

Round Prairie Township.- In the north tro-thirds of this township the drift is heavy and the bed rock is not often exposed. Most likely the Coal Measures underlie the drift over most of the territory. Some coal has been mined on the Wolf creek bottom in the northwest quarter of the southwest quarter of section 3. It was near the surface. In the tributaries of the Cedar, and on the Cedar itself, there are several places where the Coal Measures come into view. In a ravine running south in the southeast quarter of section 35 , and at a distance of about a quarter of a mile from the main creek, a sandstone, four feet thick, rests unconformably on the Saint Louis limestone. It is quite coarse, grayish white, and contained imbedded fragments of chert and fossils of the Saint Louis and was impregnated with marcasite. Farther down the same ravine there were black shales in the bank of the run. At this place some coal has been taken out by drifting in the opposite bank, and the following section is seen.

III.

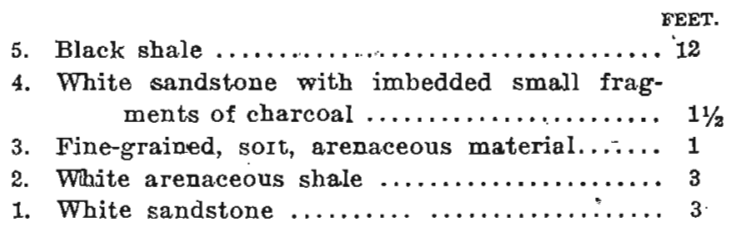

To the west, along Cedar creek, sandstone of this division appears in several places overlying the Saint Lonis uncomformably, coming down sometimes almost to the bed of the stream and sometimes resting on the limestone fifty feet up in the bluff.

Pern Township.-In the north part of this township no exposures of the Coal Measures have been observed and in all probability the Saint Lonis directly underlies the drift in most of this territory. In the south half the most productive coal 
mines in the county have been located and the formation is apparently quite continuous, though natural exposures are infrequent. Some of these are seen in the banks of South Walnut creek in the northwest quarter of section 26 , and in sections 27 and 23 , and consist of sandstone, greenish gray shales, black shalce and concretionary, discontinuous ledges of black shaly limestone, with thin seams of coal. One-fourth of a mile northwest of the center of section 32 a layer of hard sandstone containing fragments of charcoal was seen to rest on three feet of black fissile shale in the south bank of the south fork of Walnut creek. Most of the old coal banks have been located in sections $26,-i, 32,33$ and 34 , and the local character of the formation is best revealed in the explorations made in connection with these enterprises. The seam which has been mined lies about on the level of the bed of the creek. In the west half of section 26 some coal has been taken out by drifting into the base of the south bluff almost in sight of an outcrop of the Saint Louis limestone in the bed of the creek. The only mines now worked in the vicinity of Perlee are in section 27. One of these was opened this last season (1901) by Green and Looney and is located in a run on the south bluff of the south branch of Walnut creek, south of the center of the section. It is only some twenty feet deep. The coal is from three to four feet thick and is overlain by about ten feet of dark shale in which there are three layers of calcareous material. One of these lies two feet above the coal and is fine-grained and compact and traversed by many small vertical fissures, which have been filled with calcite and zinc blende. The two other layers are discontinuous and apparently more concretionary, lying respectively two and five feet above the first one. In the lower part of the dark shale a small Orthoceras, a swall Chonetes, and fragments of fish teeth were noted. North of the creek in this section several coal banks have also been in operation, one of which: lies close to the old bed of the C., R. I. \& P. railroad. The old Washington County Coal Company worked several mines in sections 32 and 33 on the south side of the south branch of Walnut creek. A section of one of the shafts used by this company is given by Keyes as follows:*

\footnotetext{
- I zwa Geol. Surp., Vol. II, p. 395.
} 
IV. SECTION OF A SHAFT OF THE WASHINGTON COUNTY COAL COMPANY. PERLEE.

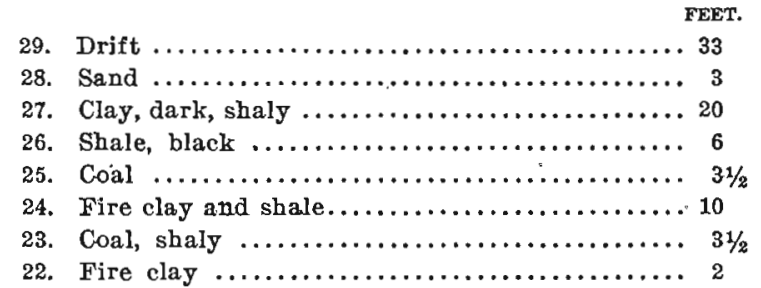

The downward continuation of this section as seen in a prospecting hole, beginning under the coal worked, is given by the same author as follows:

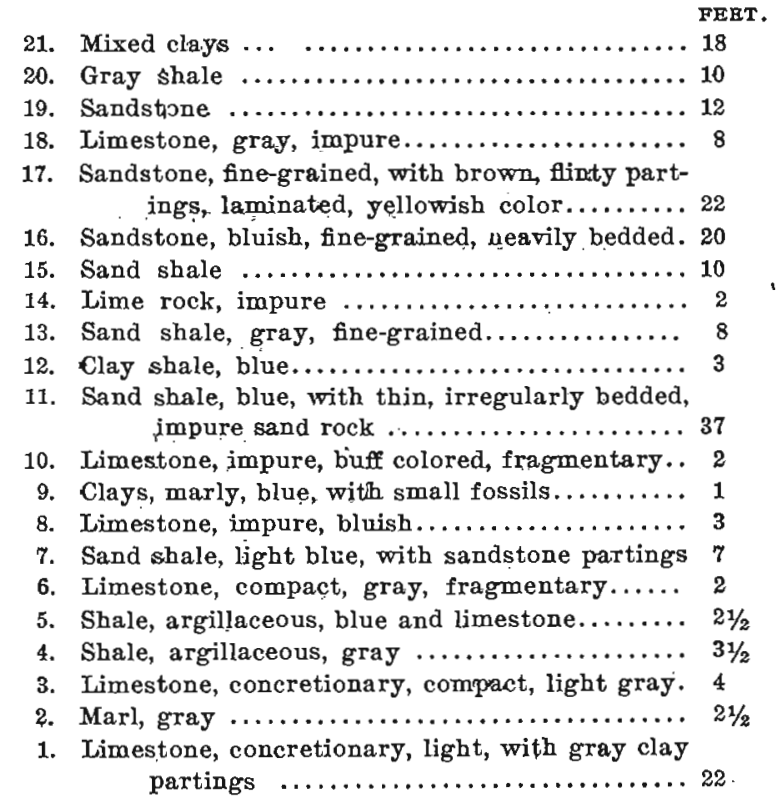

Mr. Keyes refers the lowest ten numbers in the above section to the Saint Louis. Judging from the descriptions alone, the present writer would include in this the lowest nineteen numbers. On some of the shale dumps. near the old mines in the southwest quarter of the northwest quarter of section 33 there were observed some lumps of what appears to be a mineralized 
charcoal, in which silica fills the pores of the vegetable cell worl. Some lumps were six inches in longest diameter. Part of the woody tissue bears the marks of tracheids. There were also some concretions of clay ironstone and large broken lumps of a perfectly black sandstone, consisting of crystalline quartz grains imbedded in a carbonaceous matrix. Old miners say that cakes of this material were sometimes found on the upper surface of the coal seam. All of these shafts were quite shallow, ranging from forty to one hundred feet in depth.

A partial record of the shaft of the Jefferson mine near the station at Perlee is given by Keyes, as follows:*

v. PARTIAL SECTION OF THE JEFFERSON COUNTY COAL COMPANY'S SHAFT NEAR PERLEE.

5. Shale, gray anu clayey above, becoming black, fissile below .................... 15

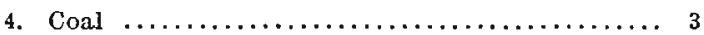

3. Fire clay, changing downward into gray clay shales .......................... 14

2. Shale, highly bituminous and coaly in places... 3

1. Fire clay, exposed $\ldots \ldots \ldots \ldots \ldots \ldots \ldots \ldots \ldots, 1$

On the old dump of this mine there were found some large pieces of silicified trunks of trees, which must have been two feet in diameter. In some of the fragments tracheids could be observed on the woody cells with a weak hand lens. There were also some fissile, gray, calcareous concretions varying from four to twenty inches in diameter and these were quite rich in fossils, such as Naulilus, sp. (small), Orbiculoidea missouriensis Shum., Orthoceras rushensis McChesney (\%) Pleurotomaria illinoisensis W., Productus muricatus N. \& P., P. nanus M. \& W., Pugnax rockymontana Marcou, $P$. uta Marcou, Schizodus alpina Hall (?), Straparollus pernodosus M. \& W. On another old shale dump of a mine on the northeast quarter of the northeast quarter of this section some more silicfied wood was noted and also some fossil-bearing concretions of a similar structure containing Clinopista radiata Hall (?), Orthoceras rushensis McChesney (?), Orbiculoidea missouriensis Schuinard, Pleurotomaria illinoisensis W., Pleurotomaria, sp. undet., Productus muricatus N.\& P., and Pugnax uta Marcou.

* Iowa Geol. Surv., Vol, II, p. 397. 
The Jefferson County Coal Company once made a drill hole on the upland slope about one-third of a mile east of the center of this section, and an old miner gives the following section of this exploration from memory:

VI. SECTION OF THE JEFFERSON COUNTY COAL COMPANY'S DRILL HOLE.

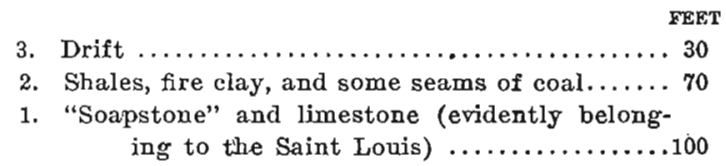

From this and the previous sections it is evident that the depth of the Coal Measures in this locality is quite limited, not much exceeding one hundred feet. The underlying Saint Louis is exposed in the creeks both to the north and to the east. A large block of limestone was observed in the bed of the creek less than three-fourths of a mile west of Perlee. While it was in such a place that it could not be with certainty said to belong to an undisturbed ledge, it evidently had not been far removed from this. The principal seam, which has been worked, is near the base of the formation and has in places been found to run out against the drift; showing that preglacial erosion extended below the level of the coal in some places. The area on which mines have been worked follows the south branch of Walnut creek a distance of about three miles, being a mile wide. The total area of the land worked is less than one square mile and most of this has not been far from the creek.

Buchanan Township.-The Coal Measures underlie the drift over the greater part of this township, but they rarely come into view owing to the comparatively small depth of the drainage valleys. Excepting some unimportant exposures in Rocky Branch the principal sections are seen on Brush creek. Coal was for some time mined by drifting into the base of the south bluff of this creek, near the northeast corner of the northwest quarter of the sonthwest quarter of section 10. This is only two miles south and one mile east of Perlee and the coal here is the same as at the latter place. On the old shale banks lumps of the same black sandstone were seen, here with impressions of the bark of trees, and associated with small indurated aggregations of charcoal. There are also the same calcareous concretions con- 
taining some of the same fossils as those near Perlee. A quarter of a mile south and a little east of the center of the section, the south bank of the creek exposes two feet of the Saint Louis limestone and underlying this there is:

VII.

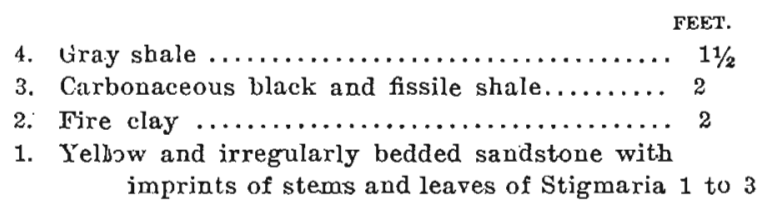

In the south bank of the creek, in the northwest quarter of the northwest quarter of section 14, a dark shale is seen which contains some clay ironstone concretions of large size, from two to three feet in diameter. In one of these the upper side consisted of a layer of cone-in-cone while the body was made up of a mass of small spherical concretions of the size of large shot and of a radiate structure. Imbedded in this mass lay some kidney-shaped concretions of black calcareous material containing fragments of brachiopods. Near the center of section 13 the north bank of the creek exposes eight feet of a dark laminated shale in which there are several bands of clay ironstone, some containing a Seminula and Lingula mytiloides. Not far from this, on the south bank of the creek, a pile of shale and an abandoned pit indicate the site of an old coal bank. In sections 27 and 35 some explorations by deep wells show that the Coal Measures are absent and that the drift rests on the Saint Louis limestone.

Cedar Township.-Most of this township is no doubt underlain by the Coal Measures, although they have been subjected to quite extensive erosion. On Crow creek, in the central sections the drift extends below the bed of the stream as far down as to the southwest of the center of section 27, below the wagon bridge, where the creek cuts into three or four feet of dark shale in the left bank. This shale contains considerable pyrites and also numerous crystals of selenitè, some of which measured four inches in length.

Going up Cedar ereek fifteen feet of dark shale is seen in the south bank at the south end of the loop which it makes to the south in the east part of section 35. A band of kidney-shaped 
concretions lie at a level a few feet above the base of this bank. In the bed of the ereek and under the shale there is a dark, and in places black, coarse sandstone, which is charged with minute grains of pyrites, that apparently had been deposited by infiltration. Some of the sandstone has a calcareous cement of similar origin, and also contains fragments of the Saint Louis limestone. This is no doubt the basal ledge of the Coal Measures resting directly on the Saint Louis limestone. A little south of the center of the northeast quarter of section 35 the east bank of the creek consists of Coal Measure shales and sandstone for a distance of twenty rods. The section is as follows:

VIII SECTION IN-THE LEFT BANK OF CEDAR CREEK NEAR THE CENTER OF THE NE. 1/4 OF SEC. 35 CEDAR TOWNSHIP.

5. Black shale, slightly calcareous and fossil-bearing at the base $\ldots \ldots \ldots \ldots \ldots \ldots \ldots \ldots \ldots, 8$

4. A layer of calcareous clay ironstone concretions. These concretions vary in size from two inches. to . nearly two feet in longest diameter. The smaller ones were found to have a core of calcite and zinc blende, while most of-the larger ones were checked internally by numerous shrinkage cracks running vertically and filled by

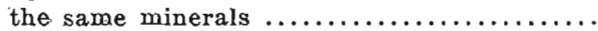

3. Black shale, laminated and fissile below, and containing in the uppermost ten inches ser, eral, fossils such as Productus semireticulatus Martin., $P$. Longispinus Sow., $P$. nanus M. \& W., P. cora D'Orbigny, spirifer camera- cus -Morton, Chonetes, sp., Seminula argentea, and quite an abundance of a simple cyathopylloid coral measuring about one and a half inches in length. In the lower part there are.numerous concretionary cakes of iron pyrites measuring some two inches in diameter with a thickness of about a half an inch $\ldots \ldots \ldots \ldots \ldots \ldots \ldots \ldots \ldots \ldots \ldots \ldots \ldots$

2. Fire clay $\ldots \ldots \ldots \ldots \ldots \ldots \ldots \ldots \ldots \ldots, \ldots \ldots, 4$

1. Sandstone, which at the point farthest south encroaches upon and replaces the fire clay. At the southernmost end a six inch seam of coal separates this sandstone from the dark shale (No, 3) above the fire clay farther

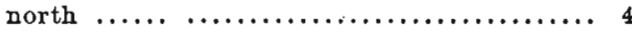


These beds exhibit a gentle syncline, rising rather abruptly at the south end as much as ten feet. This attitude is probably not due to any flexure, but rather a feature of the original deposition, caused by the uneven surface of the underlying Saint Louis. A mile farther west pockets of Coal Measure shales and sandstone are occasionally seen at varying levels on the eroded surface of the lower formation. A dark shale like numbers 3,4 and 5 in the above section, and with the same kind of concretions, appears in a ravine on the county line near the southwest corner of section 35.

For most of the distance that the creek runs in section 33 its south bank is a continuous exposure of Coal Measures in places resting upon a low ledge of Saint Louis limestone. Thus, near the east line of the section there is seen:

IX. SECTION IN THE BASAL PAR I OF THE COAL MEASURES IN THE SOUTH BANK OF CEDAR CREEK NEAR THE EAST LINE OF SEC. 33.

\footnotetext{
5. Dark shale, weathering to gray with some crystals of selenite .................... 12

4. Black, bituminous shale containing an abundance of erystals of selenite and occasional cakes of fibrous gypsum. Some crystals and cakes measured fire inches in length ....... 1
}

3. Hard, gray or grayish-brown sandstone, occasionally black or greenish black from infiltration of pyrites and other materials. Impressions of stems of Stigmaria were noted on the upper surface of the ledge ......... 2 Unconformity.

2. Greenish shale with some thin and uniformly developed laminæ of fine arenaceous material (not well exposed).............. 4 Unconformity.

1. Brecciated linestone of the Saint Louis stage, with some brecciated siliceous lumps ...... 7

The Coal Measures also appear near the center of the east line of sertion 32 and.in the south bank of Cedar creek in the southeast quarter of section 29, where they may be described as follows: 
X. SECTION IN THE SOUTH BANK OF THE CEDAR IN THE SE. 1/4 OF SEC. 29.

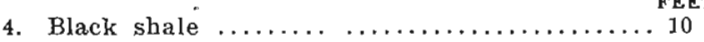
green, stony, arenaceous rock........... 11/2
green stony, arenaceous rock $\ldots \ldots \ldots \ldots$ 11/2
2. Green shale ...................... 4
Unconformity.
1. Brecciated limestone of the Saint Louis group. 3

Numbers 2 and 3 in the above are identical with number 2 in the previous section, where they occur under a coarse sandstone. They appear again a little farther to the west, where the bluff shows the following succession of beds:

$\mathrm{XI}$.

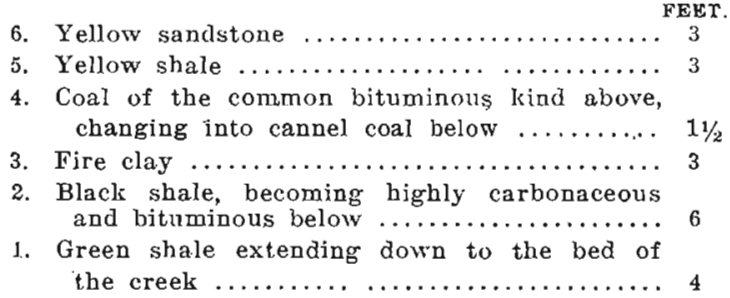

Above this place the valley of the creek is very wide and the bed rock is not so frequently seen. In section 19 coal has been mined in some shallow shafts, which are now abandoned. The strong mineral taste of the water. in several wells indicate that the Coal Measures constitute the bed rock in most of this. region.

black Hawk Township. - In this territory the drainage valleys are shallow and the bed rock was not seen anywhere. That the Coal Measures underlie at least a part of this area is evident from the records of two wells. One of these is in section 6. (See well No. 1 in the table of well records.) It is situated on upland and the first 130 feet went through drift: Below this there were thirty feet of red and black shale. The other-well is in the southwest quarter of section 27, and situated on an upland slope. Here there was eighty-five feet of drift and then shale with sandstone at the bottom. In the north the drift no doubt in some places rests on the Saint Louis, but it is probable that more than balf of the area is covered by the later formation. 
Fairfield Township.-(Excluding the tract in Tp. 71 N., R. X W.) In the three north tiers of sections the valleys are comparatively shallow and field observations on the bed rock were confined to the three south tiers. The Coal Measures underlie the greater part, if not all, of the township. All the deep wells from which records were secured entered either sandstone or shale under the drift. In the north half the thickness may average less than seventy-five feet, but in the south half it evidently averages more than one hundred feet, possibly in places reaching a depth of 150 feet. In the later region some of the wells have gone through several veins of coal, which disappear in short distances and vary considerably in thickness and elevation.

The greatest exposed depth of the formation is seen in the north bank of the Cedar near the center of the northwest quarter

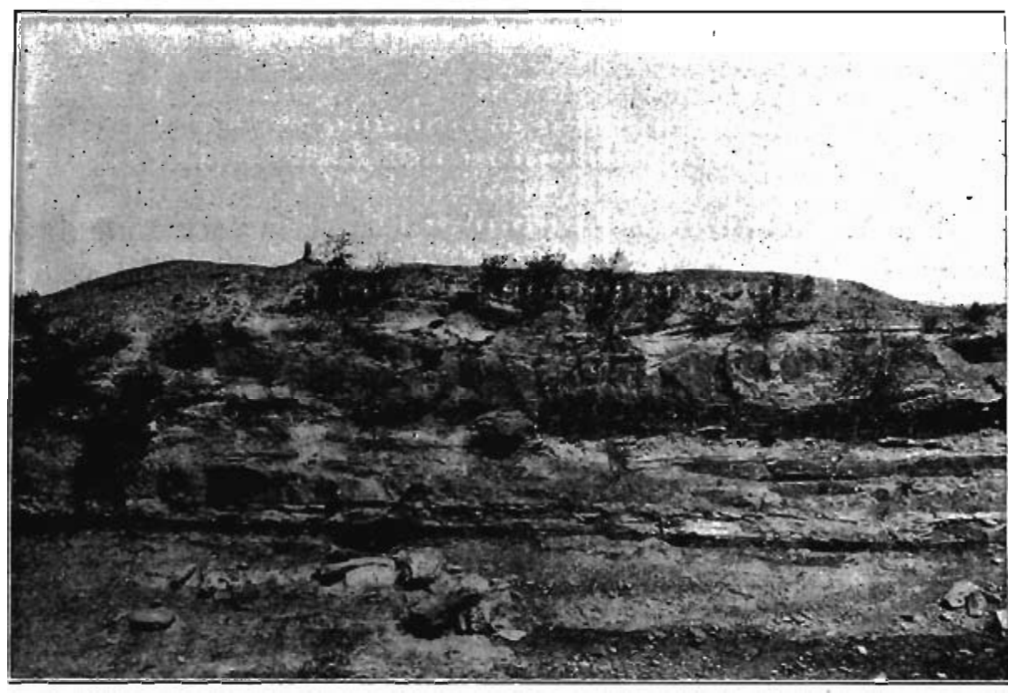

Fia. 61. Exposure of Coal Measure strata in the north bank of Cedar creek, section 32, Fairfleld township.

of section 32 , where the creek is sapping a nearly vertical embankment almost forty feet high, (Fig. 61), which may be described as below: 
XII. SECTION OF THE COAL MEASURES IN THE NORTH BANK OF CEDAR CREEK NEAR THE CENTER OF THE NW. 1/4 OF SEC. 32. 7. Soft arenaceous shale with alterating bands
6. Gray, cross-bedded and somewhat coarse sand- stone ........................... 10
5. A wedge of gray arenaceous shale, thinning towards the west................... 3
4. Gray sandstone, slightly cross-bedded and mi- caceous ............................ 7
3. Coal, thinning to the east and running out to the west, greatest thickness............. 11/2
2. Fire clay, gray and a renaceous ........... 3
1. Fire clay and shale (partly concealed) $\ldots \ldots \ldots, 7$

One-fourth of a mile south of the center of section 28 and on the west side of the wagon road where this crosses the old railroad embankment is located the clay bank of the Rainy Bros.' tile factory. The clay which is hauled away from this pit consists of a disintegrated Coal Measure shale, which is obtained by stripping, as it is covered by about fifteen feet of loess and otherdrift. The bank is at present twenty-four feet high and the material seen is

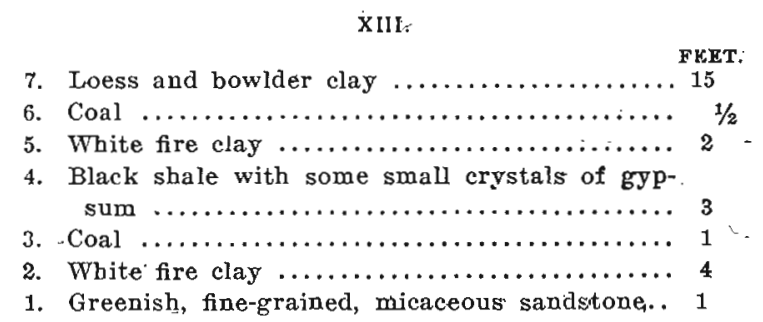

To the north along the creek in this section similar exposures. are frequent and coal has been mined here since the early day's of the settlement of this county. Several old shale- dumps areseen along a ravine which follows the south side of the old railroad in the southwest quarter of the northwest quarter of section: 27 and also in the northwest quarter of section 28. The principal coal seam occurs at depths varying from thirty to ten feet below the bottom of the streams and is from three to three and a half feet in thickness. Over it there is a black shate; which contains large septaria occasionally found to contain fossils such 
as Productus costatus Sowerby, P. semireticulatus Martin, and Spirifer cameratus Morton. Miners state that some of these septaria are very large and extend down into the coal seam so as to make il necessary to go around them with the entries. Resting on this lower black shale there is some thirty or forty feet of somewhat changeable shale containing thin seams of coal, fire clay and arenaceous material. On top of this there is a concretionary limestone, varying from one to four or five feet. This limestone has a grayish yellow color and exhibits a brecciated struciure, especially in block:s which have been subjected to weathering. On a ground surface it is seen to be cut up by an irregular network of small fissures, some of which are too small to be seen by the naked eye. There are also some vermicular, tubular cavities filled witl crystalline calcite. It is quite compact and strong and has been quarried to some extent and used in foundations. It is overlain by a black fissile miner's slate, some weathered lumps of which were seen to contain numerous specimens of Leperditia or some similar ostracod, a bone of Pleuropty clavatus Cope (identified by Eastman), and several scales, teeth and spines of fishes of unknown relationship.

In one of the wells made on section 28 it is claimed some red ochre was discovered in the shale. A sample, said to have come from this well, was examined by the writer and proved to be $\mathbf{a}$ red shale, somewhat ochreous. There may, however, have been some real ochre, as this occurs in small quantities in the same shales farther west.

Liberty Tounship. - (Including that part of Fairfield township coming within Tp. 71 N., R. X W.) In this region coal mining has been carried on for a long time at different places, though the operations have never been very extensive. At present four "banls"s" are worked, chiefiy during the winter season. The Coal Measures underlie the drift everywhere, excepting some limited areas in or near the bottom lands along Cedar creek and Iick creek. A little south of the center of the northeast quarter of section 24 , coal is mined by 1$)$. W. Bates in a ravine at a place about forty rods south of the river. The seam is variable in thickness, ranging from three to five feet, and lies at nearly the same clevation as the river bed. Another seam lies from five to 
twelve feet above this one in the bluffs at this place, separated from the lower vein by fire clay, shale and some sandstone. At an elevation of about thirty feet some coal is seen overlain by a black miners' slate and several feet of soft sandstone. Some of this coal has also been dug out by drifting into the hills.

Several other old shafts are seen to the southwest. A short distance to the northeast of the center of the southwest quarter of the section a drift is now worked by Bowen and Wilcox in the right bank of a creek. The coal is four feet thick. Above it is a black fissile shale about nine feet thick and then a sandstone. Some explorations have lately been made in this territory and the elevation of the coal seams has been found quite variable, changing as much as forty feet in less than a quarter of a mile. In the west part of section 14 and in section 15 the creek again cuts into the Coal Measures in the south bluff. In the northeast quarter of the northeast quarter of the latter section Mr. Albert Gardner now operates a shaft forty feet deep, close to the river bank. This coal lies eighteen feet below the bed of the creek. It has heen mined in several other places close by, this last shaft having been made last year (1900). A general section of the Coal Measures based upon several explorations in the region here is as follows :

XIY. GENERAL SECTION OF THE.COAL MEASURES IN THE.NE. Y OF SEC. I5

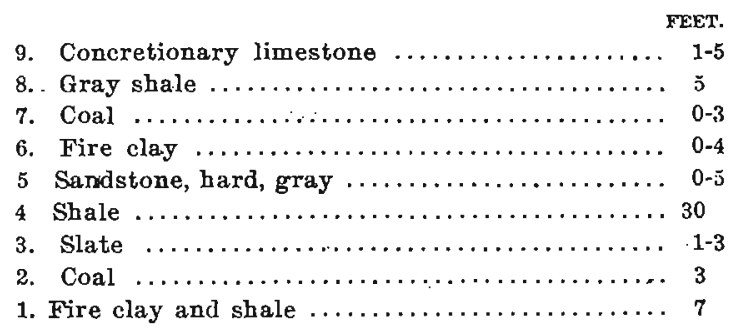

South of the wagon bridge east of the center of the north line in the same section there rests on the Saint Louis limestone the same green shale seen in the base of the Coal Measures in Cedar township. In the south bank the following succession was quite apparent: 
XV. SECTION IN THE SOUTH BANK OF CEDAR CREEK SOUTH OF THE WAGON BRIDGE IN THE NW $\angle 4$ OF THE NE. $1 / 4$ OF SEC. 15.

FEET. INCHES

6. Black, coaly shale associated with a seam of coal which was at one time mined...........

5. Concealed ......................... 2

4. Chocplate, purple and green shale......... 3

3. An indurated layer of greenish calcareous material, which is a mixture of fine sand and limestone impregnated with pyrites. It has occasional minute black fragments of fish remains. The sargest of these was a conical tooth, fluted at base, with a fine polish, and four millimeters long. Frequently the calcareous matrix shows crystalline reflections on vertical fractures. In some places this layer exhibits well formed sun-cracks............

2. Dark green shale containing calcareous septaria about an inch and a balf in diameter... 6 Unconformity, indicated by the yellow, weathered appearance of the joints in the underlying rock.

1. Limestone of the Saint Louis........... 4

In section 3 mines have been worked in several places, the principal one having been located under the north bluff southeast of the wagon bridge on the Libertyville road. The old shaft has mostly fallen in and the beds are partly concealed, but as near as it can be made out they are as follows:

XVI. SECTION IN THE NORTH BLUFF OF CEDAR CREEK EAST OF THE WAGON BRIDGE IN SEC. 3 .

FEET.

7. Gray, disintegrated shale, containing occasional crystals of selenite and a seam with large calcareous concretions containing Spififer cameratus Morton, Productus semireticulatus Martin, and-Seminula argentea Shepard..... 25

6. Coal ............................ 1

5. Sandstone, brown $\ldots \ldots \ldots \ldots \ldots \ldots \ldots \ldots \ldots \ldots$ 1-5

4. Black shale $\ldots \ldots \ldots \ldots \ldots \ldots \ldots \ldots \ldots \ldots \ldots \ldots$

3. Coal ............................. 1

2. Fire clay and shale $\ldots \ldots \ldots \ldots \ldots \ldots \ldots \ldots \ldots$

1. Coal (not well exposed, near the bed of the

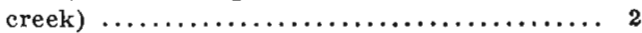

'The sandstone varies in thickness within a short distance, as do also the other beds. 
Northeast from this point, in section 2 as well as in section 3 , dark shales are seen in the ravines and there are several old mine dumps. In section 1 several wells have gone into dark shale at depths varying from fifty feet to a hundred feet. To the west, in section 5, there occurs above the shales and rising to some bundred feet above the bed of the ereek, a grayish yellow and soft sandstone. It appears in some of the ravines. West of the center of the section it is somewhat fine-grained, very micaceous and in one place orerlain directly by loess.

On Lick creek coal has been taken out for many years in the southeast quarter of section 30. Mr. A. J. Zimmerman is now operating a mine on the seutheast forty acres in this quarter. The coal is three feet thick and lies twenty feet below the creek valley. The roof consists of a calcareous and fossiliferous shale. Twenty feet above this there is a coarse and micaceous sandstone. Several shafts have also been worked on the northeast quarter of section 31. In the left bank of the creek on the south line of section 32 a black shale is exposed, which contains a thin indurated layer one side of which was covered with imprinits of Aviculopecten occidentalis Shumard, filled with bright yellow iron pyrites. A short distance up the creek a sandstone ledge is seen in the west bluff about fifty feet above the bottom.

Polk Township.-Thirty feet of dark shale was penetrated in a well in section 2. In some other wells in section 33 and 32 dark shale and coal have been found. In still others a limestone has been found under the drift. The greater part of the township is apparently covered by the Coal Measures, which have perhaps been carried away from most of the territory along the northern border. The average thickness of the formation is probably less than twenty-five feet, but near the south line it must be considerably above this average.

Locust Grove Township.-Nowhere in this township is the Saint Louis exposed. The Coal Measures underlie the drift everywhere, as far as known. In two wells they have been ex plored to a depth of eighty feet below the base of the drift and in one to about one hundred feet, and have been found to consist mostly of shale with some sandstone and coal.

27 G_Rep 
Along Competine creek shales with occasional seams of coal and of limestone appear in several places, and some coal has been mined at times, as in the southeast quarter of section 21. Near the center of this quarter there is seen in the left bank $\mathrm{cf}$ the creek:

XVII. SECTION IN THE WEST BANK OF COMPETINE CREEK, SEC 21.

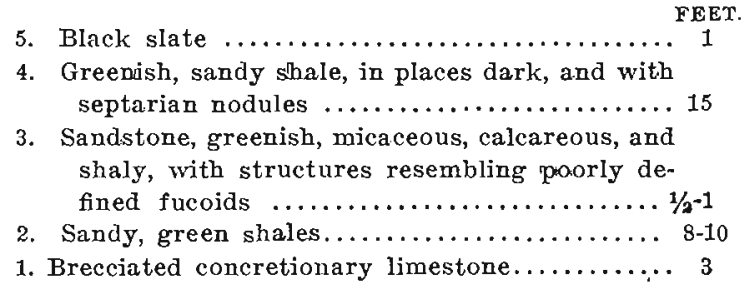

The limestone which lies in the bed of the stream at this place appears at intervals for a mile farther up the creek and a half a mile farther down. Above it are dark and sometimes black and coaly shales. In the south bank of Cedar creek in the south. east quarter of section 28, some very compact blocks of this limestone are seen and it has evidently been quarried. It is here nearly two feet thick and contains occasional small crevices filled with dark zinc blende. Where it has been subject to weathering it is seen in a hand specimen to be composed of a purplish matrix in which lie as if imbedded angular fragments of more compact limestone measuring from one-twentieth to one-half inch in diam eter. The contours of these fragments are sharply marked. The rock was otherwise perfectly compact, lacking any semblance of weak fracture planes along the surface of the fragments, breaking across the fragments and the matrix with equal facility. Another specimen showing no weathering did not exhibit such a plainly brecciated structure, but appeared as if made of well defined lumps kneaded together in a broken matrix. Numerous small and fragmentary brachiopod shells were imbedded. On top of this ledge farther up the stream was a black, highly bituminous and fissile shale, and this in turn was overlain by a more greenish shale in which there are some spherical, tough septaria of green color which have internal fissures filled with calcite and which consist of carbonate of iron and are occasionally replaced by lumps of almost pure red ochre. 
In a ravine on the northwest quarter of the northeast quarter of section 25, Mr. George Stever has a stone quarry in some ledges of sandstone. Several outcrops in the hills at this place show the following succession:

XVIII. SECTION IN A RAVINE IN THE NW. H/4 OF THE NW. $/ 4$ OF SEC 25.

4. Sandstone, micaceous, yellowish gray, more or

$$
\text { FEET. }
$$

less disintegrated $\ldots \ldots \ldots \ldots \ldots \ldots \ldots \ldots \ldots 20$

3. Sandstone, gray, coarse, hard and micaceous, in heary ledges, containing occasional balls of clay from one to five inches in diameter. A sample of the quarry rock consisted of mainly clear quartz grains, imbedded in a copious calcareous matrix. There was also some mica, a few calcareous grains, some magnetite (?), and some green quartz. The quartz grains were angular and measured mostly from one-eighth to one-half millimeters in diameter, many showing crystal faces due to secondary enlargement ............... 5

2. Cross-bedded, yellowish-gray, micaceous, disintegrated sandstone $\ldots \ldots \ldots \ldots \ldots \ldots \ldots \ldots, 8$

1. Laminated sandy shale, mixed with black carbonaceous material $\ldots \ldots \ldots \ldots \ldots \ldots \ldots \ldots, 1$

Considerable rock of a similar character has been quarried in some ravines east of the center of section 25 . In one of these ravines beds of considerable depth were noted as follows:

$X^{\prime} X$. SECTION EAST OF THE CENTER OF SEC. 25.

4. Coarse, gray, micaceous sandstone with a calcareous matrix .................. 12

3. Same as above, but softer, and in one ledge.... 8

2. Sandstone, more thinly bedded, interlaminated with shale, and having imprints of stems of

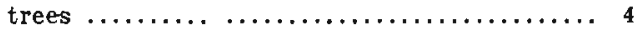

1. Cross-bedded, blue and coarse micaceous stale 10

The top of this sandstone must rise not far from a hundred feet above Cedar creek. The finer shaly beds beneath it have been excavated for filling a deep railroad embankment east of Krum. At this place they were quite disintegrated and soft. This sandy phase of the Coal Measures reappears on the south side of the valley and has furnished small quantities of stone in Rocky run in section 3 . 
Des Moines Township.-Excepting a small area on Lick creek in section 25 this whole township is underlain by Coal Measure rocks. The sandstone nated in the south part of Locust Grove township appears in sections 5 and 8 and has been quarried in some places, furnishing a fair rock for foundations. One ledge was seen to be unusually coarse-grained. Most of the stone is in thin beds, in ledges from four to eight inches. In the valley of Black creek coal has been mined for many years in different places. One mine now running is owned by Caves Bros. and located about twenty rods south of the center. of the north line of section 3). The mine is shallow, less than twenty feet deep, but the seam of the coal is fully four feet thick. In some lumps of the roof shale Lingula mytiloides was observed, and also impressions of some Lepidodendron. In the south bank of the creek the following strata appear:

XX. SECTION IN THE SOUTH BANK OF BLACK CREEK NEAR THE CENTER OF THE SW. 6 OF THE NW. 34 OF SEC. 30

3. Fossiliferous, bluish black limestone containing

FEET. a large Seminula argentea Schl., Spirifer opimus Hall, a Derbya, some bryozoa, and many joints of crinoid stems, some of which were very large $\ldots \ldots \ldots \ldots \ldots \ldots \ldots \ldots \ldots \ldots \ldots$

2. Gray shale with occasional concretions ..... 6

1. Shale, black, and changing to coal below..... 4

The limestone appears again in the same place farther down the creek. It is there cut by straight and vertical joints into large rhomboidal blocks and in places it has imbedded grains of coarse sand, together with fossils. It also exhibits lenticular thickenings, as if composed of concretions which thave become contiruous with their edges, and contains some peculiar flow structures which resemble the fucoids known as Spirophyton cauda-galli Hall. It is evident that the Coal Measures have a greater thickness in this region than anywhere else in the county and that there are two or three veins of coal, one of which is quite extensive and ranges up to five feet in thickness. Among other places where this has recently been mined is on the southwest quarter of the northwest quarter of section 32 (Frank Cloke's bank), on the northwest quarter of the southeast quarter of section 20 (Wm. Gonterman's bank), and on the northwest quarter 
of the southwest quarter of section 29 (James Gonterman's bank). In a ravine crossed by the wagon road going east and west through the southwest quarter of the northwest quarter of section 28 , and on the north side of this road the following strata were seen:

XXI.

FEET.

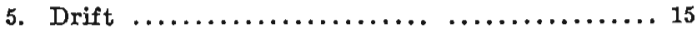

4. A seam of calcareous septaria ............ $11 / 2$

3. Gray, light shale or marl with many fossils such as Bellerophon carbonaria Cox, Chonetes mesolobus N. and P., Derbya crassa Meek and Hdn., Pleuromaria conoformis Worthen, Productus muricatus N. and P., and $P$. semireticulatus Martin .............. 5

2. Black sandstone filled with imprints of leaves. $11 / 2$

1. Coal and fire clay $\ldots \ldots \ldots \ldots \ldots \ldots \ldots \ldots \ldots, 1$

The top of this exposure lies at an elevation of at least eighty feet : bove the bed of Black creek to the southwest. As the Coal Measures are known to extend to some depth below the bed, they must have a considerable development in the region. The average tìickness for the township will probably not fall much below a hundred feet. Nor is there any doubt that productive seams of coal have a greater extent than the present explorations show.

Thickness of the Des Moines.-On the basis of the field observations as well as of the well records, approximate estimates can be made as to the thickness of the Coal Measures in the several townships. It will be seen that they average less than forty feet for the entire county and that they are heaviest in the southwestern townships. 
PLAT OF ESTIMATED AVERAGE THICKNESS OF THE DES MOINES IN THE SEVERAL TOWNSHXYS OF JEFFERSON COUNTY (IN FEET.)

\begin{tabular}{|c|c|c|c|}
\hline Polk & Black Hawk & Penn & Walnut \\
20 & 15 & 30 & 10 \\
\hline Locust Grove & Fairfield & Buchanan & 1.ockridge \\
\hline 80 & 75 & 20 & 40 \\
& & & \\
\hline Des Moines & Liberty & Cedar & Round Prairie \\
50 & 50 & 20 & 20 \\
\hline
\end{tabular}

It should be remembered that the figures given are estimates and that since both the upper and the lower limits of the formation conform to ancient erosion contours there are apt to be great local variations in its development. It is believed that the maximum development of the formation will not exceed three times the figures given, while at the same time it is known that excepting F'airfield and Locust Grove townships, the minimum limit is zero; that is, the Coal Measures have been entirely removed at some point in nearly all the townships.

In the main the Coal Measures consist of shales and sandstones. With these are associated some seams of limestone, coal and fire clay. All of these rocks vary greatly in appearance and run into each other by all possible gradations. The shales may be sandy, calcareous, or coaly; the sandstones may be shaly, calcareous or carbonaceous; and the limestones are occasionally sandy, quite often bituminous, and sometimes shaly. Representing as they do the first sediments in an advancing sea, such changes are quite natural. The very base which rests on the Saint Louis limestone is most variable. Probably in the greater number of . 
cases this consists of sandstone. In many instances it is a shale, and sometimes it is coal and fire clay. As compared with other regions it may be said that there is an absence of coarse materials in the base of the Coal Measures here. Earlier observers have noted the fact that separate beds run out in short distances in this region. No single seam of coal has been worked over any extensive region and it may be questioned if any identical seam has been traced for a distance of more than three miles. Nevertheless, there are indications that there may be discontinuous occurrences of beds of identical appearance and contemporaneous deposition in different places. This may be accounted for by supposing a considerable irregularity of the ancient shore line, allowing the making of synchronously similar as well as dissimilar deposits. The writer believes that the coal mined by Caves Bros. in section 30 of Des Moines township, is to be correlated with that mined by Mr. Smith in section 27 in Lockridge township, and at the same time it is quite evident that this seam has never been continuous between the two places. There can be nu doubt that the limestone quarried in the northeast quarter of section 28 in Fairfield township is to be correlated with that occurring in the south bank of Cedar creek in the nortbeast quarter of section 28 in Locust Grove township, while to all appearances the two areas of this limestone are separated by an intervening arenaceous phase of the formation. The same limestone occurs again some six miles northwest of Eldon, in Wapello county. As an instance of similar import may also be mentioned the recurrence at distant places of a cannel coal at elevations of from twenty-five to fifty feet from the base of the Coal Measures. This is always associated with some bituminous coal of the usual kind. There also recurs at about the same horizon a sandy, shaly and coaly limestone, which contains imprints of a structure resembling Spirophyton cauda-galli. The writer has observed this rock in the base of the Coal Measures at several places both in Illinois and Iowa, and has noted that it frequently runs out and is replaced in a horizontal direction by entirely different rocks.

Like most old sedimentary rocks this formation has acquired some secondary characteristics, chiefly through transportation and replacement of some minerals by the ground water. It is 
thus found that the grains in the sandstones in the lower part of the formation have been increased in size by secondary enlargement, and instead of being rounded usually show small crystalline faces which may glitter in the sunlight. This increases the roughness and grittiness of the rock, which is a constant and characteristic feature of the basal sandstone, and serves to distinguish it from the underlying sandstones of the Springvale beds. An occasional feature of the lowest one or two feet of the basal sandstone, and which has been noted only when this rests on limestone, is that it has had its interstices filled with iron pyrites. This gives it a black, dark gray or greenish gray color. In the shales we find that the segregation of a few minerals has resulted in the growth of crystals or concretions of various kinds. Gypsum crystals are quite frequent, varying from sizes that are barely visible to crystals five inches long. Calcareous layers have frequently gathered into concretions. In the same basin the concretions of the same seam are apt to exhibit quite constant characters as regards size, shape or internal structure. The most common mineral in these concretions is carbonate of lime with a greater or less admixture of carbonate of iron. Quite frequently these concretions are cut up by shrinkage cracks, which have been filled by crystalline calcite or else by sphalerite. In blue or greenish shales, which are rich in ferruginous materials, the concretions usually consist of a stony siderite, which on weathering turns into red ochre. Lumps of almost pure red ochre of this kind were noticed in a green shale in the banks of the Cedar creek in section 28 in Locust Grove township. 


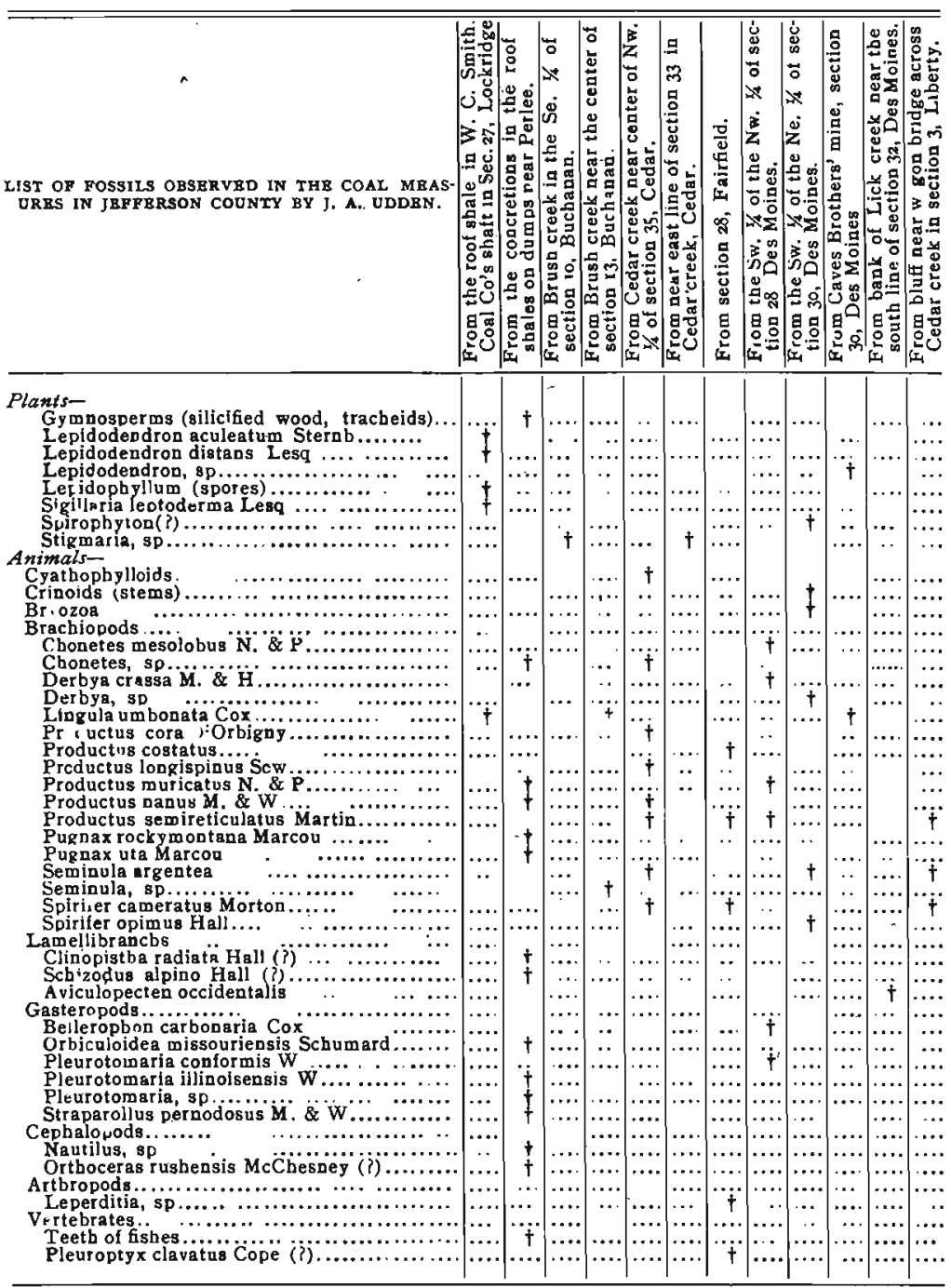

Correlations. - It is in every way apparent that the deposits containing the coal make up the base of the Coal Measures. Sandy members in this complex, and also the black shale associated with the coal seams, contain fossil plants of various kinds. 
Higher up and in the calcareous seams these give place to brachiopods and mollusks, indicating a cliange to a more open sea.

Chester Shales.-With the Coal Measures there have been described in the foregoing some green shales that rest on the Saint Louis and come in below a stigmaria-bearing sandstone at one place and below a black shale at another, on Cedar creek. Concerning these shales the writer is in doubt whether they are to be referred to the Coal Measures or not. The evidence as to where they really belong is not conclusive. They have already been sufficiently described, being number 2 in section IX, numbers 2 and 3 in section $X$, numbers 1 and 2 in section XI, and numbers 2, 3 and 4 in section XV, ranging, as will be noticed, from about four to ten feet in thickness. They exhibit a uniformity of development which is unlike anything that we are accustomed to find in the Coal Measures. Though the different points at which these beds occur are fully six miles apart, a thin seam of more indurated calcareous and arenaceous material apparently maintains itself in all the exposures, for it may be seen at an elevation of about five feet from the base of the shales at each place where this level comes into view. The only fossils found belong to this seam and consist of small fragments of fish teeth and scales. It was also seen to bear the marks of sun-cracks in one place. In all of these respects it is unlike the slaales of the Des Moines. The whole deposit also has a deeper bluish green color than the latter. An unconformity is indicated with the deposits above, but the exposures are unsatisfactory, and it may be an unconformity in the bedding, entirely local and of no significance. Lying between the Saint Louis, with which they are plainly unconformable, and the Des Moines, these shales occupy the horizon of the Chester formation known a hundred miles farther south. This formation consists largely of green shales in its northernmost extension. Possibly there was a local submergence here somewhat preceding the submergence which brought the Des Moines, and this may have been coincident with a part of the time represented by the Chester deposit farther south. The question must be left undecided at present, and local students of the Coal Measures might profitably attempt a more satisfactory solution of the problem of the equivalence of these beds. 
After the Coal Measures were deposited the bottom of the Carboniferous sea was elevated and the new land was subjected to general erosion, at least during the Triassic and Jurassic periods, and during the Tertiary age. If a submergence occurred in the Cretaceous time, the deposits of the Cretaceous sea were all removed afterward during the Tertiary age, when this region was doubtless above water. At the end of the Tertiary the land was in the main such as it would appear today, if the drift were removed. Some of the largest of the present drainage lines were already marked out, for the bed rock is still seen to rise in their sides under the drift. Possibly some of their present tributaries were also in existence at that time. The deep drift in the basin of Crow creek suggests its preglacial existence. Compared with regions lying nearer to the great rivers of the interior the preglacial topography of this county is less diversified. No deep buried channels have been found. The greatest vertical difference in the elevation of the bed rock as observed in twenty-seven wells is 110 feet. Apparently the old Tertiary plain had no greater relief than the surface of the present land. A table of these wells, with records of the materials in each case, is inserted here.

WELL RECORDS IN JEFFERSON COUNTY.

Black Hazek Township.

\begin{tabular}{|c|c|c|c|c|c|c|}
\hline No. & OWNRR AND LOCATION. & SITUATION. & 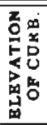 & 密 & MATERIAIS PENETRATED. & 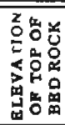 \\
\hline $\mathbf{x}$ & $\begin{array}{l}\text { T. A. Webb, Nw. I/4 } \\
\text { Sec. 6. }\end{array}$ & Up'and. & $8 \infty 0$ & 160 & $\begin{array}{l}\text { Loess and jellox bowlder clay } 60 \text { ft.; } \\
\text { dark bowlder clay, } 70 \text { It, ; red shale, } \\
\text { lo ft.; some black sba'e. }\end{array}$ & 670 \\
\hline 2 & $\overline{\text { Sec }} \frac{}{27 .}-$ Sw. $1 / 4$ & Slope. & 760 & $16 \mathrm{I}$ & $\begin{array}{l}\text { Yellow bowlder clay, } 50 \mathrm{ft} \text {; ; dark } \\
\text { bowlder clay with inclusions of } \\
\text { brown sand, } 35 \mathrm{tt} \text {.: below this there } \\
\text { was shale and then } 4 \mathrm{ft} \text {. of sand } \\
\text { rock at bottom. }\end{array}$ & 675 \\
\hline
\end{tabular}

Buchanan Torenship.

\begin{tabular}{|c|c|c|c|c|c|c|c|}
\hline 3 & $\mathbf{T}_{\text {Sec. } 27 .}^{\text {C Clover, }}$ & Sw. $/ 4$ & Upland. & $7^{\circ} 0$ & 186 & $\begin{array}{l}\text { Yellow and bluish loess and gumbo, } \\
25 \mathrm{ft} \text {; red bowlder clay and g avel, } \\
20 \mathrm{ft} \text {; dark bowlder clay to bottom }\end{array}$ & 594 \\
\hline
\end{tabular}


Buchanan Township-Continued.

\begin{tabular}{|c|c|c|c|c|c|c|}
\hline No. & OWNBR AND LOCATION. & SITUATION. & 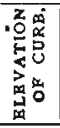 & 蜜 & $\begin{array}{l}\text { MATERIALS PANETRATED. } \\
i\end{array}$ & 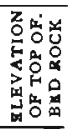 \\
\hline 4 & $\begin{array}{l}\text { J. P. Manatry, Sw. cor. } \\
\text { Sec. } 35 \text {. }\end{array}$ & Upland. & 775 & 240 & $\begin{array}{l}\text { Drift, I29 It.; limestone, } 30 \mathrm{ft} \text {; i bestard } \\
\text { rock and sandstone, } 51 \text { ft.; lime- } \\
\text { stone, soft and bluish in the lower } \\
\text { part, } 30 \mathrm{ft} \text {. }\end{array}$ & 646 \\
\hline
\end{tabular}

Des Motnes Township.

\begin{tabular}{|c|c|c|c|c|c|c|c|}
\hline 5 & $\begin{array}{l}\text { E. McCleary, } \\
\text { Sec. I. }\end{array}$ & Nw. $\quad 1 / 4$ & Upland, & 760 & 230 & $\begin{array}{l}\text { Sandy looss, } 20 \mathrm{ft} . ; \text { yellow and then } \\
\text { dark bowlder clay, 44 ft.; limestone, } \\
2 \mathrm{ft} \text {; "dark material" (probably } \\
\text { shale), } 32 \mathrm{ft} \text {; ; limesıone, 4 ft.; gritty } \\
\text { shale, } 20 \text { ft ; yellow arenaceous rock, } \\
\text { I08 ft.; water salty. }\end{array}$ & 696 \\
\hline
\end{tabular}

Fairfield Township.

\begin{tabular}{|c|c|c|c|c|c|c|}
\hline 6 & $\begin{array}{l}F \text { J. Shearer, Nw. } 1 / 4 \text { of } \\
\text { Sw. 1/4, Sec. I4. }\end{array}$ & Upland. & 785 & 165 & $\begin{array}{l}\text { Loess, } 10 \mathrm{ft} \text {; "joint clay" or gumbo, } \\
20 \mathrm{ft} \text {; red bowlder clay. } 30 \mathrm{ft} \text { i dark } \\
\text { bowlder clay, } 30 \mathrm{ft} \text {; ; white shale, } 20 \\
\text { ft ; some arenaceous material below } \\
\text { tois. }\end{array}$ & 645 \\
\hline 7 & $\begin{array}{l}\text { F. Seahill, near cen- } \\
\text { ter, Sec. I7. }\end{array}$ & Upland. & 730 & 145 & $\begin{array}{l}\text { Loess and gellow bowlder clay, } 60 \mathrm{ft} \text {.: } \\
\text { sand and gravel, Io ft.; dark bowl- } \\
\text { der clay, } 40 \mathrm{ft} \text {; sandstone in bot- } \\
\text { tom; water with mineral taste. }\end{array}$ & 670 \\
\hline 8 & $\begin{array}{l}\text { G. W. Ball, near center } \\
\text { of Sw. B Sec. Iq. }\end{array}$ & Upland. & 780 & 186 & $\begin{array}{l}\text { Drift, } 95 \mathrm{ft} \text {; sandstone, some "'dark } \\
\text { rock" and some arenaceous material, } \\
\text { with some coal and black shale, } 9 \mathrm{ft} \text {. }\end{array}$ & 685 \\
\hline 9 & $\begin{array}{l}\text { Raing Bro's Tile Fac- } \\
\text { tory, Fairfield. }\end{array}$ & Upland. & 775 & 170 & $\begin{array}{l}\text { One foot of coal in the lower part of } \\
\text { the well. }\end{array}$ & 630 \\
\hline IO & $\begin{array}{l}\text { C. W. Wbitam, Ne. } 3 / 6 \\
\text { of Se. } 1 / 4, \text { Sec. } 28 \text {. }\end{array}$ & Upland. & 750 & 230 & $\begin{array}{l}\text { Drift, I20 ft.; black sbale, fire clay } \\
\text { and several small seamo of coal } \\
\text { alternating, } 45 \text { it ; coal "6 ft." } \\
\text { alternations of shale, sand rock and } \\
\text { fire clay, with dark sandstone be- } \\
\text { low, } 59 \mathrm{ft} \text {. }\end{array}$ & \\
\hline II & $\begin{array}{l}\text { A. Freghwater, Sw. } 1 / 4 \\
\text { Sec. } 23 \text {. }\end{array}$ & Uoland. & 750 & 227 & $\begin{array}{l}\text { Dritt, ro ft.; shale, fire clay, soft } \\
\text { sandstone and small coal seams, } 46 \\
\mathrm{ft}, ; \text { thicker seam of coal, some } 4 \mathrm{ft} \text {. } \\
\text { fige, gray shale, } 7 \mathrm{ft} \text {; fine, red } \\
\text { shale, } 18 \mathrm{ft} \text {; sandstone, } 72 \mathrm{ft} \text {. (State- } \\
\text { ments as to tbis record contradict- } \\
\text { ory.) }\end{array}$ & 630 \\
\hline 12 & $\begin{array}{l}\text { B. Steever, Se. } 1 / 4 \\
\text { Sec. } 28 \text {. }\end{array}$ & Upland. & 750 & 185 & $\begin{array}{l}\text { Drift, } 80 \mathrm{ft} \text {; shale and fire clay, with } \\
\text { thin seams of coal, } 50 \mathrm{ft} \text {.; sandstone, } \\
20 \mathrm{ft} \text {.: geam of coal, } 4 \text { (?) ft.; lime } \\
\text { stone in bottom of well. }\end{array}$ & 670 \\
\hline I3 & D W Manning, Se. $/ / 4$ & Upland. & 750 & 200 & $\begin{array}{l}\text { Drift about roo ft.; dark pyritiferous } \\
\text { sandstone, } 20 \mathrm{ft} \text {; common sand- } \\
\text { atone, } 80 \mathrm{ft} \text {. }\end{array}$ & 650 \\
\hline
\end{tabular}


WEIL REOORDS.

Liberty Towrship.

\begin{tabular}{|c|c|c|c|c|c|c|}
\hline no. & OWNBR AND LOCATION & SITOATIOX. & 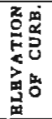 & 罟 & MATERIALS TEMETRATED. & 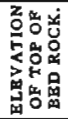 \\
\hline 14 & $\begin{array}{c}\text { L. Howard, } 1 / 4 \mathrm{mi} \text {. S. of } \\
\text { center N. line Sec. I. }\end{array}$ & $\begin{array}{l}\text { Upland } \\
\text { slope. }\end{array}$ & 750 & 985 & 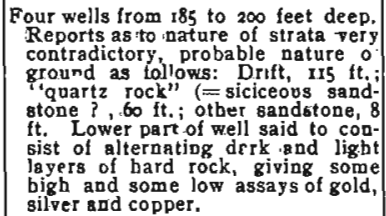 & 635 \\
\hline
\end{tabular}

Locust Grove Township.

\begin{tabular}{|c|c|c|c|c|c|c|}
\hline 15 & T. Z. Gillett, Sw. 3/4 & Upland. & 780 & 218 & $\begin{array}{l}\text { Loess and yellow bowlder clay, } 60 \mathrm{ft} \text {; } \\
\text { dark bowlder clay, \&o ft.; black } \\
\text { sba e, witb mucb pyrites, } 40 \mathrm{ft}, ; \\
\text { bluisb biack carbonaceous material, } \\
8 \mathrm{ft.;} \text { saudstone, shale and fire clay, } \\
30 \mathrm{ft} \text {. }\end{array}$ & 640 \\
\hline 16 & J, D. Baird, Se. $/ / 4$ Sec. 4 & Upland. & 780 & 200 & $\begin{array}{l}\text { Drift, Iso ft.; conl in lower } 50 \text { feet of } \\
\text { well. }\end{array}$ & 640 \\
\hline 17 & T. W. Gobble, Ne, $1 / 4$ & $\begin{array}{l}\text { Upland } \\
\text { slope. }\end{array}$ & 740 & 188 & $\begin{array}{l}\text { Yellow drift, } 30 \mathrm{ft} \text {; dark bowlder } \\
\text { clay, } 60 \mathrm{ft} \text {; gravel, is ft.; black } \\
\text { abale, } 80 \mathrm{ft} \text {. }\end{array}$ & 632 \\
\hline 18 & $\begin{array}{l}\text { L. A. Patterson, Ne. } \\
\text { corner Sec. ro. }\end{array}$ & Upland. & 750 & 160 & $\begin{array}{l}\text { Loess ro ft, gumbo, ro ft.; yellow } \\
\text { bowlder clay. } 40 \mathrm{ft} \text {; dark bowlder } \\
\text { clay, } 60 \mathrm{ft} \text {.; sandstone, mostly fine } \\
\text { but somewbat coarser below, } 40 \mathrm{ft} \text {. }\end{array}$ & 630 \\
\hline 19 & T. W. Hill, Sec. $3 \mathbf{I}_{1}$ & $\begin{array}{l}\text { Creek bot- } \\
\text { tom. }\end{array}$ & $7 \infty$ & 200 & $\begin{array}{l}\text { Some gravel at about } 60 \text { feet below } \\
\text { surface. Thirty incbes of coal at } \\
\text { II5 feet below surface. A bard } \\
\text { sandstone in the bottom. }\end{array}$ & 635 \\
\hline \multicolumn{7}{|c|}{ Penn Township. } \\
\hline 20 & J. Pascha, center Sec. I. & Upland. & 760 & 130 & $\begin{array}{l}\text { Loess and yellow bowlder cley, } 60 \mathrm{ft} \text {; } \\
\text { some sand; dark bowlder clay down } \\
\text { to } 100 \text { teet below curb of well; lime- } \\
\text { stone with some sand, } 30 \mathrm{ft} \text {. }\end{array}$ & 660 \\
\hline 21 & $\begin{array}{l}\text { M. Polus, Nw, } 1 / 4 \text { Sec. } \\
\text { z4. }\end{array}$ & Upland. & 730 & 106 & $\begin{array}{l}\text { Loess and yellow clay, } 50 \mathrm{ft} \text {-; dark } \\
\text { bowlder clay, } 53 \mathrm{ft} \text {; gravel, } 3 \mathrm{ft} \text {. }\end{array}$ & $704(?)$ \\
\hline \multicolumn{7}{|c|}{ Polk Townshis. } \\
\hline 21 & $\begin{array}{l}\text { L. K, Wallace, Sw, cor. } \\
\text { Sec. } 2 \text {. }\end{array}$ & $\begin{array}{l}\text { Draw in up- } \\
\text { land. }\end{array}$ & 820 & 300 & $\begin{array}{l}\text { Drift and loose clay, i6o ft. ; dark } \\
\text { shale, } 30 \mathrm{ft} \text {; limestone witb cbert, } \\
\text { lo ft. }\end{array}$ & 660 \\
\hline 23 & $\begin{array}{l}\text { Goo. E. Estes, W. } / 2 \\
\text { Sec. } 16 .\end{array}$ & Upland. & 8 ro & 186 & $\begin{array}{l}\text { Limestone with some chert at Io ft. } \\
\text { sandstone at It4 ft., continuing } \\
\text { with changes of texture and hard- } \\
\text { ness to I } 86 \mathrm{ft} \text { " No sbale or coal." }\end{array}$ & $700(?)$ \\
\hline
\end{tabular}


Polk Townshtp-Continued.

\begin{tabular}{|c|c|c|c|c|c|c|}
\hline No. & OWNBR AND LOCAIION. & SITUAIION. & 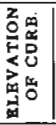 & 产 & MATERIALS PBNETRAiED. & 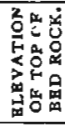 \\
\hline 24 & r. R. Smith, Se, $1 / 4 \mathrm{Sec}$. & Upland. & 780 & 79 & $\begin{array}{l}\text { Dark drift from } 10 \text { to } 75 \text { feet below } \\
\text { surface; ghale about } 3 \mathrm{ft} \text {. }\end{array}$ & 705 \\
\hline 25 & $\begin{array}{l}\text { A. T, Downey, W. } 1 / 2 \\
\text { Sec. 33i (just } \\
\text { Abingdon. of }\end{array}$ & Upland. & 760 & 75 & $\begin{array}{l}\text { Drift, } 70 \mathrm{ft}, \text {; shale and coal in bot- } \\
\text { tom. }\end{array}$ & 690 \\
\hline
\end{tabular}

Round Prairie Township.

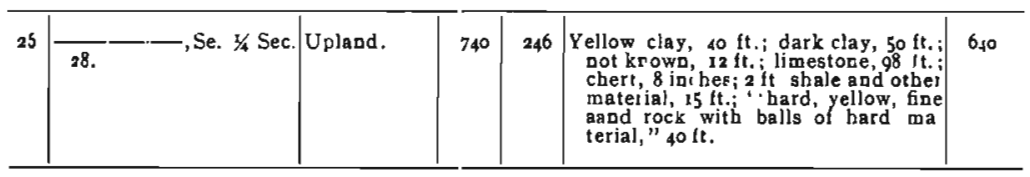

Walnut Townshtp.

\begin{tabular}{|c|c|c|c|c|c|c|}
\hline 27 & C. Schaffer, E. $1 / 2$ Sec. & Upland. & 720 & 240 & $\begin{array}{l}\text { Drift, 60 ft; " rock acd sbale," } 180 \mathrm{ft} \text {; } \\
\text { hard ock, (= limestone?) in bot- } \\
\text { tom. }\end{array}$ & 660 \\
\hline
\end{tabular}

\section{The Pleistocene.}

Subsequent to the Tertiary age extensive glaciers invaded this rogion from the north and laid down sheets of bowlder clay which now cover most of the north central states. With the overlying loess and associated gravels and sand this bowlder clay is commonly called the drift. In Jefferson county the average thickness of the drift is 115 feet, including the loess and the bowlder clay and disregarding local reduction by subsequent erosion. It exceeds this depth in Buchanan and Cedar townships and falls below it in Walnut and Des Moines townships.

Associated Gravels. - In the eastern part of the county a few places were noted where gravels and sands rest on the bed rock and are covered by bowlder clay. The most extensive exposure of this kind is at the southwest corner of section 1, Walnut township, in the south bank of a ravine, which is fed by a number of springs that issue from the gravel at intervals for a distance of some thirty rods. The deposit is fully twenty feet thick and lies at an elevation of about 100 feet above Skunk river. To the west it is covered by bowlder clay and for a mile in this direction 
there are wells in which the water comes from the same gravel, and has a strong mineral taste. The deposit is highly ferruginous and almost ochreous, brownish yellow in color, and in places cemented into a soft stone. The lower part is a gravel, but the upper fifteen feet is an evenly bedded, laminated sand of variable texture, with here and there silty seams. Deposits like this, but more silty, were noted in the base of the drift at two other localities in this region; on the wagon road at a shallow draw near the center of the west line of the northwest quarter of section 12 in Walnut township and at the base of the bluff in the wagon road which leads down to the ford across Skunk river in the east half of the southeast quarter of section 11 in Lockridge township. Some indurated brown gravel or sand was again noted in the south bank of a ravine above the wagon bridge near the southeast corner of section 24 in Round Grove township. The section at this place was as follows:

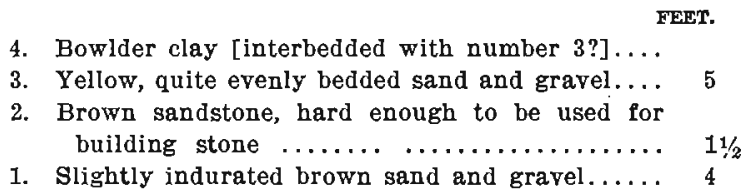

The same gravel occurs in the two next streams which cross the east boundary of the county to the south of this place, and it was also noticed, resting on the bed rock, in two ravines running into Cedar creek in the southwest quarter of section 35.

The age of this gravel is problematical. Judging from its position it may be of preglacial or Tertiary age., But it can as well be glacial. In favor of the latter view is the fact that it contains a great deal of Archæan material, and against it the fact that among 500 pebbles which were examined none were found to be scored, and further that the proportion of different rocks seems very variable at different localities. Glacial gravels are usually composed of the same materials in quite constant proportions in the same region. In local Tertiary river gravels we would be apt to find a greater diversity in the assortment of materials along different drainage lines. The degree of induration and the thoroughness of oxidation and leaching also indicate a considerable age for these gravels. Calcareous materials are 
almost entirely absent. Some unique pebbles testify to this extensive leaching. On section 1 , in Walnut township, the gravel contains some pebbles of limonite, which are hollow. They are of the shape and size of an empty shell of a hazel nut. Presumably these limonite shells have been formed as incrustations around calcareous pebbles, which afterward have been leached out by slow percolation through the crust, leaving this empty. The following table gives the proportion of the different materials represented among pebbles measuring about one-half inch in diameter for four different localities:

\begin{tabular}{|c|c|c|c|c|c|}
\hline KINDS OF ROCES. & 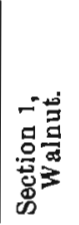 & 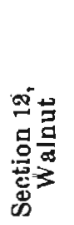 & 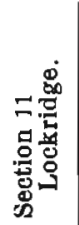 & 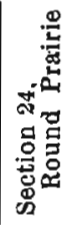 & 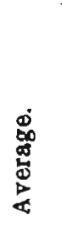 \\
\hline 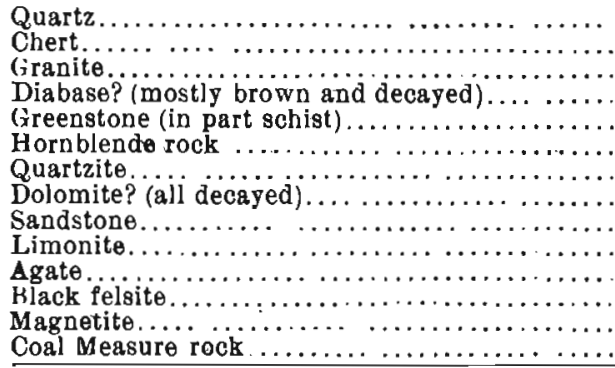 & $\begin{array}{r}18 \\
29 \\
22 \\
9 \\
9 \\
1 \\
2 \\
8 \\
2 \\
9 \\
1 \\
\cdots \\
\cdots\end{array}$ & $\begin{array}{r}17 \\
44 \\
15 \\
7 \\
4 \\
0 \\
2 \\
0 \\
2 \\
7 \\
0 \\
1 \\
1\end{array}$ & $\begin{array}{r}11 \\
40 \\
3 \\
3 \\
8 \\
6 \\
5 \\
5 \\
5 \\
6 \\
8 \\
1 \\
1 \\
\cdots \\
\cdots \\
\cdots\end{array}$ & $\begin{array}{r}8 \\
2 \\
88 \\
12 \\
12 \\
32 \\
0 \\
2 \\
0 \\
4 \\
4 \\
0 \\
\ldots \ldots \\
\cdots \cdots \\
\ldots 2\end{array}$ & 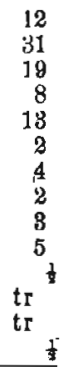 \\
\hline
\end{tabular}

If these gravels are to be regarded as belonging to the glacial deposits they may belong either under the lowermost or Albertan drift or above this under the Kansan. The overlying bowlder clay resembles the Kansan, but it is in a locality where the earlier bowlder clay may have been removed, before the Kansan drift came. .Hence, it is impossible to determine whether these gravels are Tertiary, Albertan or whether they are to be correlated with the Aftonian.

The Bowlder Clays. - There are two bowlder clays in this region, deposited at two different times: the Albertan, or preKansan, and the Kansan. The Albertan rests on the bed rock or on a thin seam of gravel or sand. It is dark bluish gray or almost black and quite hard and tough. Some well makers in 
this county even call it "hardpan," which is a misnomer. It frequently contains pieces of wood of gymnospermous trees and angular fragments of coal. On the uplands this bowlder clay averages sixty feet in thickness, and is seldom less than thirty feet or more than seventy. Here as elsewhere it is apt to contain seams or pockets of yellow sand and occasional streaks of peaty material, especially near the bottom and near the top. Small crystals of gypsum were observed in one place. It is not often seen in typical exposures along the streams, but is always found under the uplands in making wells.

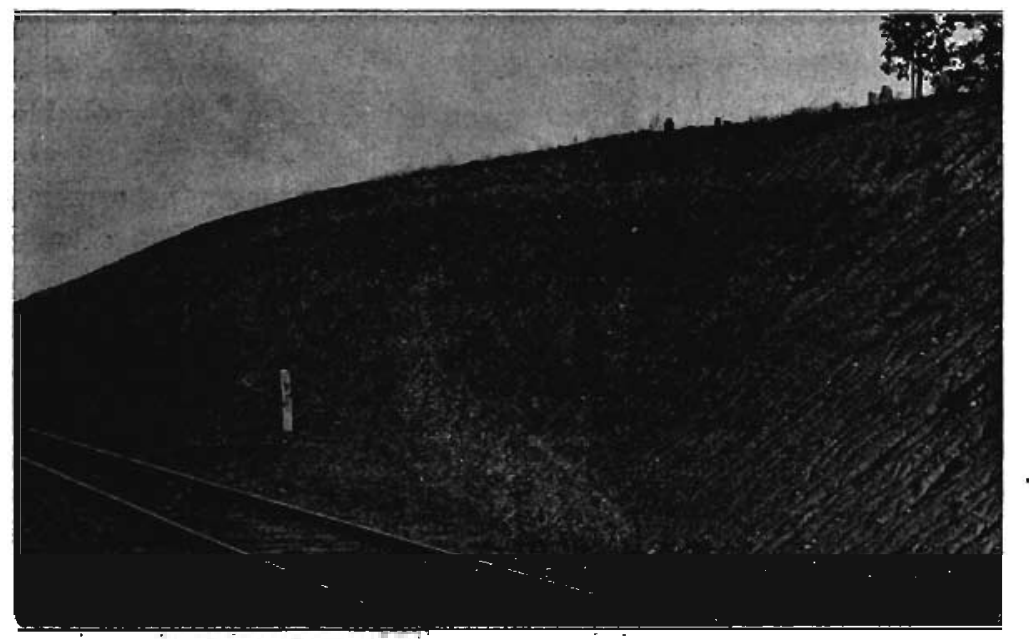

Fic. 62. Kansan drift overlaln by loesg, one mile west of Fairfield.

On top of the Albertan is a yellow or light gray bowlder clay which has been called the Kansan. This is sometimes sharply marked off from the Albertan, either by a decided change in color or else by intervening streaks or pockets of yellow sand. This must be regarded as an equivalent of the Buchanan gravels. More often the two clays merge gradually into each other, the change taking place through several feet of vertical extent. The Kansan drift seldom, if ever, contains any pieces of wood or of coal. In places it is somewhat sandy and open to the ground water, while at other places it is changed above into a grav, sticky 28 G Rep 
and slippery earth called "gumbo," which is almost impervious to water. From this all calcareous materials are removed. Near the east line of section 29 in Fairfield township the new railroad cuts expose fifteen feet of such gumbo, under the loess. The embankments have slid down on the road bed and it has been found necessary to lay tile to drain the ground more promptly. The leaching of the Kansan is quite variable in depth, changing, in some places, from four to twelve feet in a few rods. This appears to be due to difference in texture, or perhaps also to difference in drainage. In a few localities the Kansan drift was sandy and obscurely stratified about ten feet below its upper sur. face. It frequently contains calcareous concretions at the base of its upper leached part.

To secure if possible some evidence bearing on the probable difference of origin of the two bowlder clays a study was made of the frequency of different kinds of rocks among the erratics of each. About one thousand pebbles, collected in lots of one hundred from ten localities in each bowlder clay, were classified and tabulated. It was then found that the Keweenawan rocks, such as hornblende rock, diabase, gabbro, epidote, a red arkose, and also chert, were slightly more frequent in the Kansan and that Huronian rocks such as greenstone, some schists, slate, jaspilite, syenite, and Paleozoic rcoks, such as dolomite, limestone, clay ironstone, shale, pyrites and coal, were more common in the pre-Kansan, or Albertan drift. Granite, quartz, quartzite, sandstone and Cretaceous pebbles were present in about equal quantities in both tills. This difference, though slight, may be said to corroborate the evidence found elsewhere that the Albertan and the Kansan till were laid down by two different glacial sheets, that had somewhat divergent lines of transportation, the former coming more directly from the north and the latter more from the northeast, where the Keweenawan rocks predominate. The greater abundance of local and Paleozoic rocks in the lower drift is most likely due to the fact that much of the Kansan must consist of the Albertan ground over a second time, when the softer sedimentary rocks would suffer more attrition than the more durable igneous and metamorphic erratics. To see to what different extent different rocks suffered reduction in the glacial mill 
we need only ascertain the variations of percentage which the several rocks make in assemblages of erratics of different sizes. The result of some observations of this kind on the erratics in this county are given in the table. below:

TABLE SHOWING THE PERCENTAGE OF DIFFERENT KINDS OF ROCKS AMONG ERRATICS OF DIFFERENT SIZES IN THE BOWLDER LILAYS OF JEFFERSON COUNIY.

\begin{tabular}{|c|c|c|c|c|c|c|c|}
\hline \multirow{2}{*}{. KUNDS OF ROCKS. } & \multicolumn{7}{|c|}{$\begin{array}{c}\text { AVERAGE DIAMETER (IN INCHES) } \\
\text { OF ERRATICS }\end{array}$} \\
\hline & 81 & 27 & 9 & 8 & 1 & $\frac{1}{8}$ & 1.9 \\
\hline quartz........ & & & & L & 1 & $\mathbf{3}$ & \\
\hline Granite......... & 90 & 64 & 43 & 27 & 20 & 15 & 23 \\
\hline Greenstone ...... & & 3 & 11 & 7 & 5 & 7 & \\
\hline Hornblende rook. & & 2 & 2 & 2 & 1 & 1 & \\
\hline Schists.......... & $\ldots$ & . . & 1 & 1 & 1 & 2 & \\
\hline syenite... & $\ldots$ & $\ldots$ & 1 & 1 & $\ldots$ & tr & \\
\hline 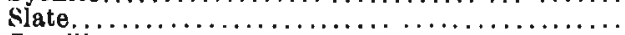 & & $\ldots$ & & .... & .... & tr & \\
\hline 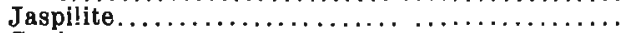 & & & . & 1 & ... & $\mathbf{t r}$ & tr \\
\hline Gneiss............ & & $\mathbf{3}$ & 4 & 2 & 1 & & \\
\hline Diabase and gabbro ......... & 10 & 10 & 16 & 26 & 31 & 13 & 10 \\
\hline Other dark eruptives..... & $\therefore$. & 1 & 2 & 1 & 8 & 1 & \\
\hline 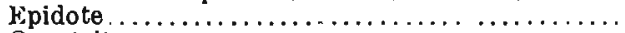 & $\ldots$ & $\ldots$ & & & & tr & \\
\hline 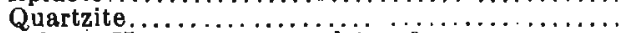 & & $\cdots$ & 5 & 2 & 3 & 2 & \\
\hline A rkose (Keweenawan sandstone?) . . . . ........ & & & 2 & 2 & 2 & 1 & $\operatorname{tr}$ \\
\hline 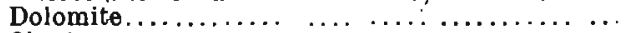 & $\ldots$ & 4 & 1 & 4 & 5 & 11 & 10 \\
\hline Chert $\ldots \ldots \ldots \ldots \ldots \ldots, \ldots, \ldots, \ldots \ldots \ldots$ & $\ldots$ & 1 & 2 & 7 & 8 & 8 & \\
\hline Limestone $\ldots \ldots \ldots \ldots \ldots \ldots \ldots \ldots \ldots \ldots \ldots$ & $\ldots$ & $\hat{9}$ & 5 & 10 & 10 & 24 & 22 \\
\hline 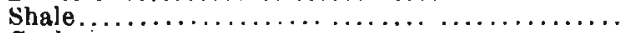 & $\ldots$ & $\therefore$ & $\ldots$ & $\cdots$ & $\ldots$ & 1 & tr \\
\hline 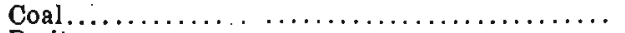 & $\ldots$ & $\ldots$ & $\ldots$ & . & $\ldots$ & $\operatorname{tr}$ & \\
\hline 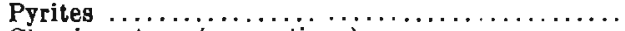 & $\ldots$ & $\cdots$ & $\cdots$ & $\cdots$ & & 1 & \\
\hline 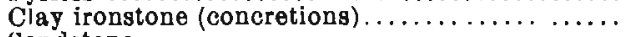 & $\ldots$ & & 1 & 2 & 5 & 3 & \\
\hline 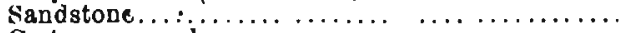 & $\ldots$ & 1 & 4 & 3 & 5 & 2 & \\
\hline Cretaceous rock $\ldots \ldots \ldots \ldots \ldots \ldots \ldots$ & & & & & & & \\
\hline
\end{tabular}

It will be noticed that the largest bowlders are granite, with a few consisting of diabase and gabbro. It may be added that the largest bowlder seen in the county measures $17 \times 12 \times 7$ feet, and lies on a slope one-fourth mile east of the northwest corner of section 15 in Walnut township. It is a porphyritic granite with twinned orthoclase crystals an inch and a half long, all oriented in the same plane. Tro pieces of native copper have been found in the drift in this county, one in Des Moines township and one in Locust Grove, the former weighing twelve pounds and the latter about eight ounces.

Loess.-The bowlder clay is everywhere covered with loess, which averages about twelve feet in depth in this county. From 
the reports of well makers it appears somewhat heavier than this on the upland divides, but on the edge of the slopes it is often only eight or ten feet. It usually contains no calcareous materials. These appear to have been leached out. "Loess-kindchen" are very rarely found. Fossils were assiduously looked for, but none were seen. In the east bluff of Skunk river just across the east boundary of Walnut township and near the town of Coppack in Henry county, this formation is quite different; it is considerably thicker, somewhat more coarse and open in texture, it is calcareous and contains small fossil snails. This same phase runs northwest in the bluffs and no doubt underlies an acre or two of land in the extreme northeast corner of Jefferson county, though this could not be verified by direct observation. On the low edge of upland which forms the east bluff of Cedar creek east of the Chicago, Burlington and Quincy railroad bridge in Locust Grove township, the base of the loess exposed along the road-bed contained a thin dark seam, in which some spherical nodules of impure wad were imbedded. Nodules of this kind are occasionally found in boggy places in the upland loess in Illinois.

Alluvial Deposits. - These form the terraces and bottom lands along the the streams. The former consist of pebbly, bedded clays and sands generally concealed under a thin mantle of loess. The clays are usually calcareous. Owing to the general presence of a loess-like mantle they are seldom exposed. On the bottom lands yellow sand usually lies under a yellow silt. The latter is frequently like loess in texture and varies from five to fifteen feet in thickness.

A Pleistocene Fossil.-In the bed of Walnut creek, where it follows a rocky cliff in the west half of the southwest quarter of the northwest quarter of section 28 in Walnut township, Mr. Josia Bates some years ago found the lower jaw of Elephas americanus. Both molars were well preserved and the entire specimen weighed fifty pounds. From sketches taken by the writer, Professor Calvin infers that the specimen is from an animal slightly undersized, between fifty and sixty years of age. To what part of the drift it belongs is not evident.* 
Geological Structure.

The several formations lie almost horizontally in Jefferson county. If there is a general dip to the southwest, it is small and the amount cannot be accurately estimated. Some small local dips are known. The Saint Louis limestone, especially in the upper beds, is often affected by some dome-like flexures, which commonly are only a few rods in diameter, and where the center is elevated two or three feet above its height around the dome. In the extensively brecciated ledges a fault with a downthrow of four feet was noted in one exposure in the north part of Lockridge township, Small deformations of this kind are probably incident to underground collapsed caverns and to brecciation and dolomitization of the Saint Louis beds.

Joints. -The bearings of sixty-seven joints in the Saint Louis limestone were taken in different parts of the county. On plotting these in a circle it appears that they are almost uniformly distributed to all the different points of the compass, indicating absence of any general dip.

\section{Unconformities.}

Discontinuity of deposition occurs certainly at two, and possibly at three, horizons in the formations, viz: (1) above the Saint Louis, (2) possibly above the green shales referred to the Chester (?) in the base of the Coal Measures, and (3) above the Coal Measures. Each of these horizons represents an interval when the sediments of the region wero elevated above the sea

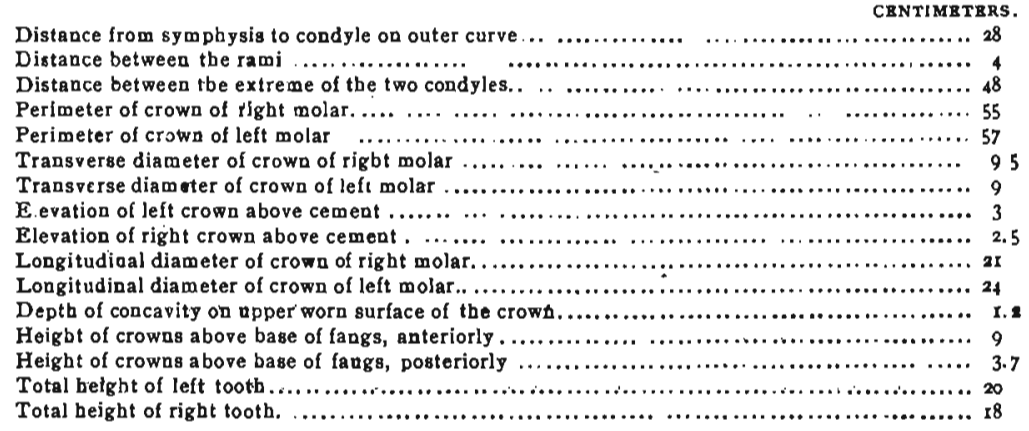

* Some measurements were taken as follows: 
and subjected to erosion, and none give evidence of any appreciable concomitant tilting. They are all unconformities without dip. Places where the unconformity above the Saint Louis may be seen are not numerous, and nowhere does the base of the Coal Measures happen clearly to overlap the eroded ledges of the underlying Saint Louis. That the erosion interval was quite extensive is nevertheless evident from the fact that the latter formation in some places rests on the upper divisions and elsewhere on the lower divisions of the Saint Lonis. Thus in sections 9 and 10, Liberty township, the Coal Measure shales rest on Pella marls and limestones, but under the bridge near the center of section 23 in the same township the underlying limestone is arenacesus and evidently belongs to the Verdi division. On Wolf creek and at some places on Brush creek the Pella beds also appear, but on Cedar and Walnut creeks the Coal Measures are again often found resting on the Verdi, and the Pella beds are absent. On Cedar creek, in Round Prairie township, the upper formation rests on the lower at levels both above and below the Pella beds, and reliefs of forty or fifty feet on the surface of the Pella beds are evident. Sometimes the Coal Measure shales and sandstones extend down into cavern-like or ditch-like excavations in the surface of the limestone. Sucli instances have been described in sections 9 and 10, in Liberty township, and were noted in some of the sections on T'urkey creek. A doubtful case of unconformity has been mentioned under the heading "Chester Shales?" It occurs above a green shale lying below the base of the undoubted Coal Measures, in Cedar and Round Prairie townships on Cedar creek, as already set forth. During the Mesa zoic and the Tertiary ages the land was again subjected to erosion, which was most extensive and protracted, and this period is recorded in the unconformity between the Paleozoic rocks and the drift, which is everywhere in evidence. The drift may rest on any of the members of the older rocks at elevations varying at least a hundred feet. But even here no great general tilting is apparent. Even this unconformity is, in the main, an unconformity without dip.

Glacial Scorings.- Some obscure glacial scorings were seen on the south bank of the middle fork of Walnut creek northeast of 
Perlee. They were made on the surface of a broken ledge of the Saint Louis limestone and were covered by calcareous yellow till, only the edge of the ledge being exposed. There were two sets of scorings, one trending S. $75^{\circ} \mathrm{W}$. and the other S. $35^{\circ}$ E., as near as could be made out. The exact locality is immediately to the west of a ford across the stream in a private road about twenty rods west of the old Chicago, Rock Island and Pacific railroad bridge and about thirty rods east of the west line of section 23 in Penn township.

\section{ECONOMIC PRODUCTS.}

\section{Building Stone.}

A]though there are considerable quantities of building stone no extensive quarries have yet been opened. This is probably due to the fact that the best rock is not found in the most accessible places, and perhaps also to the quite general distribution of accessible ledges yielding fairly good stone, in almost every township. This latter circumstance has to some extent prevented centralization of the industry. At some time or other rock has been quarried at probably not less than half a hundred different places, but not one quarry is now worked the year round, or even continuously during one season. The Pella beds contain several ledges, which vield dimension stone and material for bridge work. Extensive quarries might be opened and worked at several points along Cedar creek in Round Prairie and Cedar township. Soft and easily worked sandstone might be quarried at no great distance from the new line of the Chicago, Burlington and Quincy railroad east of Krum. The sandstones of the Coal Measures in Liberty and Cedar townships might in many places yield large, strong and durable blocks and slabs, such as may be seen at the old Lamson residence on Cedar creek bluff, southwest of Fairfield. •

-It may not be amiss to here correct a misuse of the name "granite" which seems common among some quarrymen in the west part of the county who take out "granite" from the ledges of the Coal Measures in that region. The rock which is here generally known by that name is a fair quality of sandstone, in which the sand is cemented together by 
a copious calcareous matrix. It is a strong rock, except in places where it has been subjected to weathering. But the application to it of such a name, which is entirely erroneous, might easily occasion distrust among competent workmen and thus prevent or delay its general introduction, even for purposes to which it is well adapted.

\section{Clay.}

Only two firms are engaged in the manufacture of brick and tile. Kainy Brothers operate a drain-tile and brick factory immediately west of the city of Fairfield. It is located on the south side of the Chicago, Burlington \& Quincy railroad, just west of the city. The value of the plant is estimated at $\$ 15,000$. Some nineteen men are employed, and last year the company made and sold about 700,000 brick and 800,000 tile, the former retailing at $\$ \tau .50$ and the latter at from $\$ 10.00$ to $\$ 60.00$ per thousand, according to size. The tile is usually dark in color. It is strong, durable and uniformly well burnt. Considerable quantities of a twelve iuch tile without rim are made, and this has

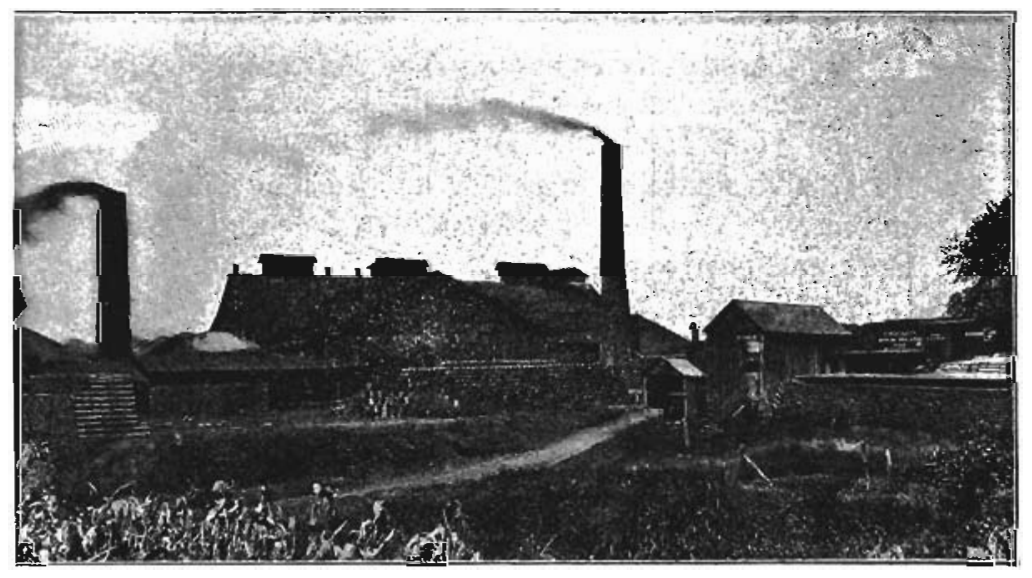

FIa. 83. Rainy Brothers' brick and tile factory, Fairfield.

been used for sewers in Fairfield. Two kinds of clays are used. The clay pit near the plant contains loess above and a leached gumbo below. Both the loess and the gumbo are entirely free 
from lime. With this is mixed a weathered Coal Measure clay in proportions varying from one-third to one-half of the whole. Each is first ground or thoroughly crushed and then the two ingredients are mixed in a pug mill. The Coal Measure clay contains a large amount of fire clay and is hauled a distance of a mile and a half. Drying is by steam, and all burning is done in five down draft kilns. Most of the tile is exported to the west part of the state, to Chariton, Creston, Shenandoah, Milo and Dallas Center. Most of the brick is consumed by the home market, but some has been shipped for sidewalks to outside places, notably to Lenox and Kent. The Keb coal, from near Ottumwa, is exclusively used in the kilns.

Downey \& Mitchell operate a brick and tile factory at Packwood: About 150,000 brick and as many tile are made in a year. Five men are usually employed. A twelve horse power engine runs a soft mud machine. The product is all dried in a shed and burnt in two down draft kilns. Brick brings $\$ 8.00$ per thousand and four inch tile $\$ 13.00$. Nearly all the tile made is of this size. Most of it is sold in the home market, and the rest is freighted to the nearest stations. The clay used is a leached and weathered upland loess.

In conclusion it may be said that this county has an abundance of well weathered clays at a number of localities, suitable for the manufacture of brick and tile.

\section{Coal.}

A detailed account has already been given of the distribution and character of the Coal Measures, and it is hardly necessary to say much here on the economic side of the same subject. The Jefferson County Coal Company, operated some mines at Perlee from 1870 to 1884 . About 100 acres of coal were taken out. They supplied the Chicago, Rock Island \& Pacific Railroad company with an average of about eighty tons a day for fourteen years. The Washington Coal Company also operated quite extensively for several years at the same place. Still earlier considerable quantities of coal were for many years shipped from the mines northwest of Lockridge. At present only one mine ships coal and its annual output does not exceed 3,000 tons. This is the 
W. C. Smith Coal Company, near Lockridge. The decline in price of coal is regarded as the chief cause of the late decline in the industry. Small mines, or "banks," are worked, usually only in the winter, at a number of places, as may be seen from the statistical table below. Occasional mining or quarrying of coal is also done by the farmers. It is safe to say that coal has at one time or another been taken out at half a hundred different places throughout the county.

A glance at the geological map shows that this region is on the edge of the Coal Measures. To the north they have been carried away by erosion. Even in the south part of the county they have frequently been cut through by the streams. Probably there are places on the uplands where they are absent under the drift in the south and in the middle tiers of townships. It has been shown that the contained coal seams are very changeable, thinning out and disappearing in short distances. At times there is no coal in the shales and sandstones which remain. This unreliable character of the seams has interfered with extensive mining, and no doubt always will.

On the other hand, it cannot be doubted that many times more workable coal yet remains than has been taken out. An examination of the location of the mines will show that they have invariably been located on outcrops along the streams, or in the vicinity of such places. Not one mine has been located by prospecting on the uplands away from the streams. Evidently such localities have suffered least from erosion and the best chances for coal ought to be there. But such prospecting will always be expensive. It must be thorough and it should be done by competent and reliable men. No one should undertake it without sufficient means. The writer believes that workable seams of coal may be found by prospecting on the uplands, especially in Des Moines, Liberty and Locust Grove, and probably also in Penn, Buchanan, Fairfield, Cedar, Round Prairie and Lockridge townships. 
STATISTICAL TABLE OF COAL MINING IN JEFFERSON COUNTY.

\begin{tabular}{|c|c|c|c|c|c|c|c|}
\hline OPERATOR'S NAME. & $\begin{array}{l}\text { LOCATION OF MINE BY TOWN- } \\
\text { SHIP AND SECTION. }\end{array}$ & $\begin{array}{c}\text { NATURE OF } \\
\text { MINE. }\end{array}$ & 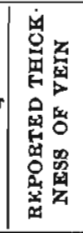 & 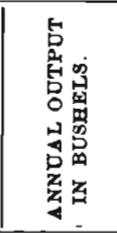 & 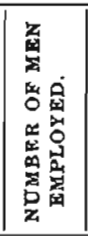 & 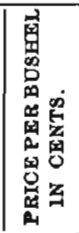 & MARKET. \\
\hline 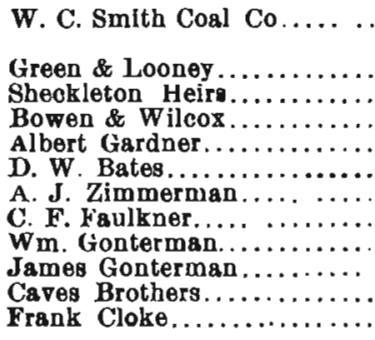 & 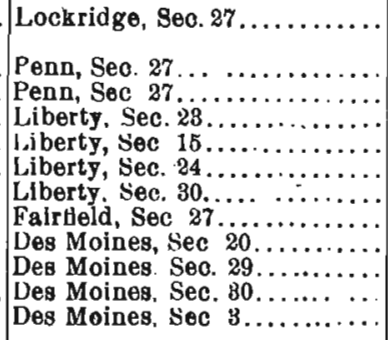 & 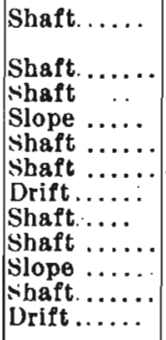 & \begin{tabular}{|l}
4.5 \\
$\cdots$ \\
$\cdots$ \\
4 \\
3 \\
3 to 5 \\
4 \\
$\cdots \cdots$ \\
4 \\
4 \\
2 \\
8
\end{tabular} & 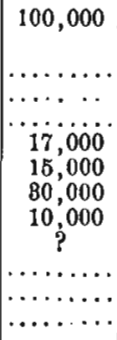 & $\begin{array}{r}10 \\
\cdots \cdots \\
\cdots \cdots \\
\cdots \\
4 \\
4 \\
5 \\
\cdots \cdots \\
\cdots \cdots \\
\cdots \\
3 \\
2\end{array}$ & 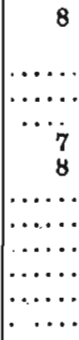 & $\begin{array}{l}\text { Mt. Pleasant, New } \downarrow \text { on. } \\
\text { don, home. } \\
\text { Home. } \\
\text { Home. } \\
\text { Hairfield, home. } \\
\text { Hine Fairfeld. } \\
\text { Home. } \\
\text { Home. } \\
\text { Hairfield. } \\
\text { Home. } \\
\text { Home. } \\
\text { Home. } \\
\text { Home }\end{array}$ \\
\hline
\end{tabular}


Water Resources.

The general level of the ground water has steadily and gradually sunk throughout this region since it has come under cultivation. The change ranges from five to thirty feet. In the city of Fairfield shallow wells must now be made from ten to fifteen feet deeper than in the early days of the settlement to secure water. Near the broken tracts following the streams shallow wells have begun to fail entirely and farmers are now beginning to drill deep wells drawing water from the bed rock. To insure a good and constant supply, such wells should go through the Coal Measures and into the Saint Louis, except in places where the former consist largely of sand rock. Owing to the variability in the development of the Coal Measure strata, deep wells in this county must also necessarily vary and no general rule can be laid down for well makers here. This is shown by past experience, and uncertainty of results is one of the reasons wrhy, as yet, comparatively few deep wells have been made. The uplands on the divides in Polk and Black Hawk townships constitute an exceptional region. Here the underground drainage is almost stagnant and the water lingers on the surface of the Kansan till at the base of the loess and there is vet a constant supply which can be reached at depths varying from fifteen to twentyfive feet.

The water-works at Fairfield were built in 1884. They consist of a standpipe eighty feet high and twelve feet in diameter and a pumping station with two fifty horse power engines. The level of the base of the standpipe is thirteen feet below the level of the public square. Two deep wells were used for a short time at first, but proved unsatisfactory. Two reservoirs were then constructed, which are supplied with a sufficient supply of surface drainage from a natural basin (park) located north of the city. The city has four and a half miles of water mains with forty hydrants and 400 taps. In 1900 thirty-eight million gallons were pumped.

\section{Soils.}

The soil is mostly loess. On the flat uplands the black mould is from two to four feet deep. On a divide east of Fairfield it has been rich enough in carbenaceous material to be used for the 
making of railroad ballast. On the slopes the soil consists of weathiered bowlder clay with a superficial admixture of loess. In such places it contains a few small pebbles. On the high terraces along Cedar creek there is a greater admixture of fine clayey material and the soil is more adherent and more retentive of moisture. In dry seasons it becomes quite hard. The soil on the bottom land is invariably a rich black loam. The only place in the county where there is a more open and sandy soil is on the south bluffs of the Cedar in sections 4, 5 and 6, in Liberty township. In this vicinity some of the farmers have engaged in the raising of small fruit and garden truck. The thorough leaching of the ground in this county has left a small amount of carbonate of lime near the surface as compared with some other parts of the state, and it is probable that an artificial supply of this mineral might improve the soil in some places on the flat uplands.

\section{ACKNOWLEDGMENTS.}

In the work on this county the author has received valuable aid from Professor S. Calvin, the director of the Survey; frum A. G. Leonard, Assistant State Geologist; from Dr. Schuchert, of the Smithsonian Institution; from Dr. Eastman, of the Harvard Museum, and from Dr. Sardeson, of the University of Minnesota. 


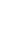




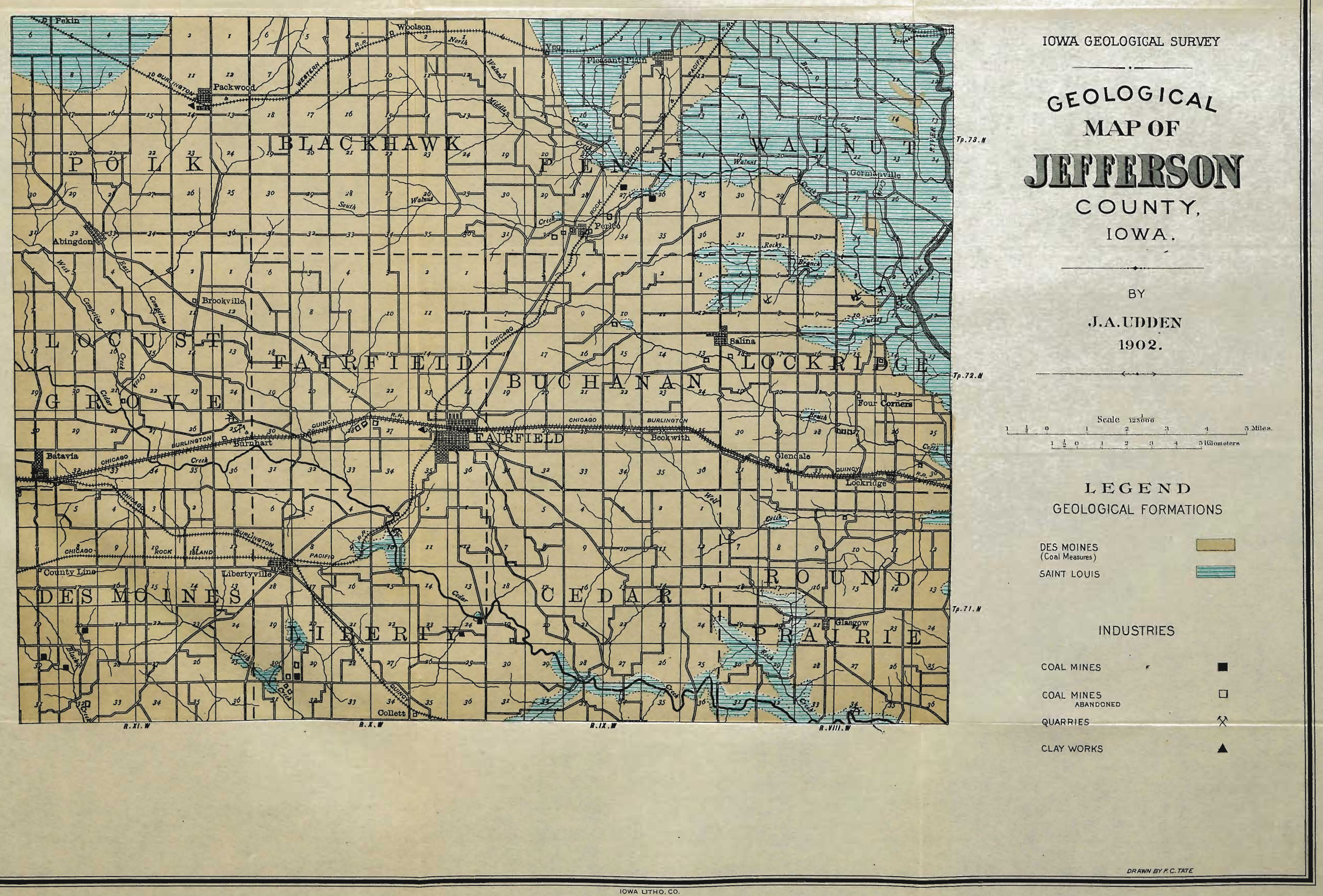

